\title{
Brown v. Board of Education and the Symbolic Uses of Supreme Court Decisions in American Politics
}

\section{Brown v. Board of Education and the Symbolic Uses das decisões da Suprema Corte em Política Americana}

\author{
Jeffrey D. Hockett ${ }^{1}$
}

\begin{abstract}
American legal education is predicated upon the assumption that legal meaning is found within the opinions that accompany judicial rulings. The history of the United States Supreme Court's desegregation decision suggests that reality is more complicated than the conventional wisdom suggests. Indeed, the iconic status of Brown v. Board of Education (1954) was in significant measure a function of scholarly efforts to substitute a rationale - that the ruling was an attack upon white supremacy - for the Court's controversial social science-based opinion. Subsequent to Brown, scholars have contested the import of the ruling for constitutional controversies involving race. Conservative scholars contend that a proper interpretation of this decision is one that is grounded in the color-blindness principle. By contrast, liberal intellectuals attempt to square Brown with the racial subordination principle - that government may not reinforce the subordinate status of a racial group but may employ racial classifications to aid the victims of discrimination. Certain considerations, however, reveal that the nature of this dispute is ideological rather than legal. The group terms in which Brown characterized
\end{abstract}

\footnotetext{
${ }^{1}$ Professor and Chair; Department of Political Science; University of Tulsa, Oklahoma-USA
} 
the psychological harms of segregation contravened the individualistic premises of the color-blindness principle, while the narrow context of the judicial process prevented the justices from acknowledging the complex notion of social reality that informs the racial subordination principle. The upshot of these considerations is that the meaning of Supreme Court decisions is related to the efforts of scholars and political actors to use those decisions - especially iconic rulings - as powerful symbols in partisan battles.

Keywords: Brown v. Board of Education; American legal education; race; Supreme Court decisions.

\section{Resumo:}

A educação jurídica americana baseia-se no pressuposto de que o significado legal é encontrado nas opiniões que acompanham as decisões judiciais. A história da decisão de segregação da Suprema Corte dos Estados Unidos sugere que a realidade é mais complicada do que a sabedoria convencional sugere. De fato, o status icônico de Brown v. Board of Education (1954) foi em grande medida uma função dos esforços acadêmicos para substituir uma lógica - que a decisão era um ataque à supremacia branca - para a polêmica opinião baseada na ciência social do Tribunal. Subsequentemente a Brown, os estudiosos contestaram a importância da decisão de controvérsias constitucionais envolvendo raça. Os estudiosos conservadores afirmam que uma interpretação adequada desta decisão é fundamentada no princípio da cegueira de cor. Em contraste, os intelectuais liberais tentam marcar Brown com o princípio da subordinação racial - que o governo não pode reforçar o status subordinado de um grupo racial, mas pode empregar classificações raciais para ajudar as vítimas de discriminação. Certas considerações, no entanto, revelam que a natureza desta disputa é ideológica e não legal. Os termos do grupo em que Brown caracterizou os danos psicológicos da segregação violaram as premissas individualistas do princípio da cegueira de cor, enquanto o contexto estreito do processo judicial impediu os juízes de reconhecer a noção complexa de realidade social que informa o princípio da subordinação racial. O resultado dessas considerações é que o 
significado das decisões da Suprema Corte está relacionado aos esforços de estudiosos e atores políticos para usar essas decisões - especialmente decisões icônicas - como símbolos poderosos em batalhas partidárias.

Palavras-chave: Brown v. Board of Education; Educação jurídica americana; raça; decisões da Suprema Corte.

\section{Introduction}

Few scholars would dispute the contention that Brown v. Board of Education of Topeka, Kansas" "is the single most honored opinion in the [United States] Supreme Court's corpus."2 But the prevailing consensus regarding Brown's greatness should not lead one to overlook the fact that the desegregation decision was (and remains) the object of scholarly controversy. In the years immediately following the decision, liberal thinkers as well as segregationists questioned Brown's legitimacy. A common charge was that traditional sources of constitutional interpretation did not support a holding that racial segregation in elementary and secondary schools violates the equal protection clause of the Fourteenth Amendment. ${ }^{3}$ Even some proponents of the notion of a "living Constitution" challenged the Court's claims regarding the inherent inequality of segregated schools, which supposedly justified judicial recognition of a right that conflicted with precedent and the intentions of the framers of the equal protection clause. ${ }^{4}$ Brown's greatness was a function, not of the Court's rationale, but of the brutality of the southern response to desegregation efforts. The violence that southerners directed at peaceful civil rights protesters and at black school children served to deprive segregationists of benign characterizations of apartheid and to solidify the ethical appeal of the desegregation decision. Scholarly recasting of the ruling as an attack upon an institution that could only be characterized as a manifestation of white supremacy proved an effective response to the objections of Brown's more legalistic critics. ${ }^{5}$

The cessation of battles over the legitimacy of Brown in no way implied the discontinuance of scholarly conflicts over the decision. Indeed, the iconic status that the 
desegregation decision eventually achieved inspired disputes of equivalent intensity over the legacy of the ruling. Most obviously, Brown is central to the debate over the "living Constitution" concept. Supporters of the view that judges should regard constitutional rights as broad principles not wedded to the subjective intentions of the framers of a provision typically present Brown as a symbol of the promise of this method of constitutional interpretation. Brown's moral authority is of such weight that certain scholars who champion a constitutional jurisprudence of original intent have responded by defending a position that even the members of the Supreme Court in 1954 declined to embrace - that Brown can be reconciled with the intentions of the framers of the Fourteenth Amendment. ${ }^{6}$

A more apposite line of inquiry from the view of the majority of scholars (including originalists) who accept Brown's irreconcilability with traditional materials of constitutional interpretation concerns the decision's import for current constitutional controversies involving race. Regarding themselves as defenders of the rule of law, proponents of originalism insist upon judicial adherence to a proper interpretation of Brown, namely, one that links the decision to the color-blindness principle. In viewing the decision as an historic statement against racial classifications of any sort, these scholars find particularly disturbing (and portray as a regrettable departure from the principle and spirit of Brown) the Warren Court's insistence that desegregation be measured by actual results, as opposed to the mere abandonment of segregation laws. They also object to the Burger Court's approval of court-ordered busing and racial quotas as equitable remedies for school segregation and rejection of challenges to certain forms of affirmative action. By contrast, supporters of the notion of the "living Constitution" find troubling the Rehnquist Court's greater hostility toward "benign" or "benevolent" racial classifications and the justices' apparent understanding that racial discrimination occurs only in discrete instances. These scholars regard the Court's performance as a lamentable retreat from the racial subordination principle that the justices of the Warren Court supposedly enunciated in Brown, namely, that government may not act to reinforce the subordinate status of a racial group but may employ racial classifications to aid the victims of discrimination. 
The vulnerability of both interpretations of the Brown decision is revealed by scholars from each jurisprudential position who, ironically, are more receptive to their opponents' reading of the import of the opinion (but who blame the decision for the more recent, controversial equal protection rulings). On the one hand, some originalists suggest that Brown, by discussing in group terms both the psychological harms of segregation and the matter of relief, contravened the individualistic premises of the colorblindness principle. On the other hand, some supporters of the "living Constitution" concept contend that the Brown decision did not observe the racial subordination principle, since the narrow context of the judicial process precluded judicial acknowledgment of the complex notion of social reality that informs that principle - one that points up the extensiveness of and white responsibility for racial oppression.

These criticisms (and the difficulties originalists have in grounding their opposition to "benevolent" racial classifications in the framers' intentions) suggest that the contemporary debate over Brown's import is, at base, a controversy over competing interpretations of social fact, as opposed to a principled disagreement over the requirements of the rule of law. Originalists reject the view that a strong linkage exists between racial group membership and social status, and they thus maintain the lack of the need for (and the dangerousness of) remedial racial classifications. "Living Constitution" proponents reject the view that racial discrimination occurs only in discrete instances, and they thus maintain the need for (and the benign nature of) affirmative action measures. The efforts of both sides to the current controversy to enlist the moral authority of Brown reveal that the Supreme Court is limited in its ability to control the meaning of its decisions. In the same way that Brown's legitimacy stemmed in part from scholarly recasting of the ruling as an attack upon white supremacy, Brown's legacy, if resolved, will be a function partly of a contest among political forces that seek to use that decision as a potent symbol to advance their respective goals.

\section{Brown, Originalism, and the "Living Constitution" Concept}

\section{Brown as Bludgeon}




\section{Originalist Criticism of the Warren and Burger Courts.}

While Brown is perhaps the most respected decision in the history of the Supreme Court, the praise that scholars have heaped upon that decision is inversely proportional to the criticism that a number of other Warren Court rulings have received. Indeed, under Earl Warren, the Court generated enormous controversy across a range of areas of constitutional law, including the First Amendment's freedoms of speech, press, and religion, as well as the procedural protections of the other amendments of the Bill of Rights. No less controversial were the Court's use of the due process clause of the Fourteenth Amendment to apply many of the provisions of the Bill of Rights against the states; its recognition of a general, unenumerated right of privacy; and its use of the equal protection clause of the Fourteenth Amendment to restructure the electoral systems of the states. $^{7}$ The Warren Court even sustained severe criticism in the area in which it achieved its greatest constitutional victory - equal protection and race. In a unanimous ruling handed down fourteen years after Brown, the justices held that desegregation would be measured by actual results, and obliged southern states to eliminate (presumably through "benign" racial classifications) the racial imbalance in public schools that remained after the legal framework of segregation was dismantled. ${ }^{8}$ Summarizing the responses of the Warren Court's critics, Milton Handler observes: "Eminent scholars from many fields have commented upon [the Court's] tendency towards overgeneralization, the disrespect for precedent, even those of recent vintage, the needless obscurity of opinions, the discouraging lack of candor, the disdain for the fact finding of lower courts, the tortured reading of statutes, and the seeming absence of neutrality and objectivity." 9

Not surprisingly, scholars who favor a jurisprudence of original intent as against the notion of a "living Constitution" are among the Warren Court's most vocal critics. According to Raoul Berger, "[t]he list of [Warren Court] cases that would fall were the 'original understanding' honestly applied is indeed formidable." The justices' disregard for the original intentions behind relevant constitutional provisions carried the enormous "cost of warping the Constitution" and of "undermining "the rule of law." Indeed, with considerable overstatement, borne of a confusion between unrestrained judicial review 
and unfettered executive power, he maintains that the Court's non-originalist decisionmaking "perilously resembles the subordination of 'law' to the attainment of ends desired by a ruling power which was the hallmark of Hitlerism and Stalinism."10 Robert Bork's description of the Warren Court as "a Court that had spun out of control" echoes Berger's indignation, if not his effort to link the justices with two of the twentieth century's most hated tyrants. He claims that the Warren Court's inattentiveness to the original understanding of the Constitution "led to some of the law's most blatantly illegitimate decisions." A complete treatment of the Court's rulings that contravene originalist premises, he believes, "would take up an entire book."11

Originalists find many of the rulings of the Burger Court equally troubling. Bork speaks for countless others when he describes the Court's expansion of the right of privacy to include a woman's decision whether or not to terminate a pregnancy as "the greatest example and symbol of the judicial usurpation of democratic prerogatives in this century." 12 Originalist critics of the Court find its receptiveness toward "benign" or "benevolent" racial classifications only slightly less objectionable than the abortion ruling. Gary McDowell believes Congress should have exercised its constitutional powers to regulate the appellate equity jurisdiction of the Supreme Court when the justices committed a "constitutional usurpation" of authority by giving their unanimous approval to lower court usage of mathematical ratios as goals for the racial composition of public schools and to court-ordered busing to effectuate pupil transfers between schools. ${ }^{13}$ And Bork refers to the continued "moral imperialism of the Supreme Court" when speaking of the Burger Court's interpretations of Title VII of the Civil Rights Act of 1964. He objects, in particular, to the Court's ruling that ostensibly neutral employment practices are unlawful if plaintiffs merely present evidence of a disparate racial impact (as opposed to proof of discriminatory purpose); and he laments the Court's decision that Title VII's prohibition of racial discrimination does not condemn all private, voluntary, race-conscious affirmative action plans. Such rulings, he argues, "made of the 1964 Civil Rights Act a law that Congress had not written."14

Since Bork believes that the intentions behind the equal protection clause (as well as those behind the Civil Rights Act) preclude all racial classifications, "benign" or otherwise, he necessarily regards as unjustifiable the Court's ruling, in Regents of the 
University of California v. Bakke, ${ }^{15}$ that universities may consider racial criteria as part of an admissions process, as long as fixed quotas are not employed. Bork surmises that such receptiveness to racial classifications for ostensibly remedial purposes is the product of an "intellectual class bias" toward egalitarianism that partakes of "a moralism so strong that it overcomes positive law."

\section{Brown's Relevance.}

Powerful and widespread though such criticism may be, contemporary detractors of the "living Constitution" concept must contend with a jurisprudential factor that was not present when originalists attacked Brown in the 1950s - the moral authority of the Brown decision itself. As Michael McConnell notes: "[W]hat was once seen as a weakness in the Supreme Court's decision in Brown" - namely, the decision's nonconformity to originalist premises - "is now a mighty weapon against the proposition that the Constitution should be interpreted as it was understood by the people who framed and ratified it." Indeed, "[s]uch is the moral authority of Brown that if any particular theory [of judicial review] does not produce the conclusion that Brown was correctly decided, the theory is seriously weakened." 17 Bork is equally cognizant of the relevance of Brown to contemporary debates over the merit of the "living Constitution" concept. He observes that Brown - "the greatest moral triumph constitutional law ha[s] ever produced" - "has become the high ground of constitutional theory." And, like McConnell, he notes that "those who wish to be free of the restraints of original understanding in the hope that courts will further a particular policy agenda regularly seek to discredit that philosophy by claiming that it could not have produced the outcome in Brown." 18

Scholarly use of the Brown decision to critique originalism and thus defend the "living Constitution" concept actually takes two forms. Some scholars, whom John Wofford typifies, elaborate upon the Court's reference in Brown to the difficulties of

discovering the intentions behind constitutional provisions. ${ }^{19}$ Wofford identifies several factors that complicate judicial efforts to ascertain the "state[s] of mind" of those persons involved in the framing and ratification of a constitutional provision, including an 
incomplete historical record and the likelihood that relevant historical figures possessed differing interpretations of identical language. These impediments become nearly insurmountable, he believes, when one considers that relevant historical figures include the numerous ratifiers as well as the framers of a constitutional provision. Wofford contends that the judicial task is no more likely to be successful if judges reconceptualize the search for intent to involve the seemingly more manageable charge of discovering the "common meanings" that Americans of the relevant time period ascribed to constitutional language. For the most likely indicator of that meaning - the concrete actions of these persons - may well fall short of the ideal that people understood the constitutional provision to represent. Finally, any effort to avoid these problems by limiting the search for intent to a search for the specific purpose or "evil which the constitutional provision was designed to remedy" is likely to founder on the same difficulty that plagues efforts to discover states of mind, namely, the problem of multiple interpretations. In view of the practical difficulties associated with originalism, Wofford concludes, "it was proper for the Court in deciding whether racially segregated schools violated the equal protection clause to examine closely the function of public education, not only at the time the fourteenth amendment was enacted, but as it has developed over the years." In the same way, it is appropriate for contemporary justices "not [to] search for a binding past purpose" and, instead, to consider provisions in light of current circumstances. ${ }^{20}$

The strength of the evidence that segregationists marshaled to demonstrate the historical illegitimacy of Brown makes the decision a questionable choice to illustrate the practical difficulties of originalism. ${ }^{21}$ But, ironically, the segregationists' historical case against Brown reinforces the second, more formidable response to originalist criticism of the Court (and the scholarly usage of Brown to which McConnell and Bork refer) - that this method of constitutional interpretation brands the most celebrated Supreme Court decision an illicit constitutional amendment. As Michael Perry observes: "[I]f the Court's [abortion] ruling...were illegitimate - as many of the Court's critics insist it is on the ground that it is not explicable by reference to any of the framers' value judgments, the Court's ruling in Brown would have to be deemed illegitimate too, since neither ruling was the outcome of interpretation or application of any value judgment constitutionalized by the framers." 22 
The logical implication of Perry's observation is contained in Ronald Dworkin's defense of the view, which the NAACP's lawyers also favored and championed before the Supreme Court in $1953,{ }^{23}$ that judges should regard abstract constitutional provisions as appeals to broad principles of morality, not necessarily connected to the particular understandings of the provisions' framers. Unlike originalism, Dworkin emphasizes, this method of constitutional interpretation (i.e., the "living Constitution" concept) enables judges to conclude "that racial segregation is inconsistent with the conception of equality the framers accepted at a more abstract level," that "fidelity to their convictions as a whole requires holding segregation unconstitutional." 24

As the latter statement implies, Dworkin goes so far as to suggest that the "living Constitution" concept can be justified from an originalist as well as a policy perspective. Put another way, the Supreme Court's refusal to respect the specific understandings behind constitutional provisions in Brown and other contemporary cases, ironically, represents the fulfillment, rather than the nullification, of the framers' intentions. In defense of the view that originalism is self-refuting, Dworkin contends that "vague' [constitutional] standards [such as the due process and equal protection clauses] were chosen deliberately, by the men who drafted and ratified them, in place of the more specific and limited rules that they might have enacted." Such abstract constitutional terms, he avers, are most naturally viewed "as representing appeals to the [broad moral] concepts they employ, like legality [and] equality," as opposed to "botched or incomplete or schematic attempts to lay down particular conceptions," examples, or understandings of political morality. ${ }^{25}$

Dworkin's originalist defense of the "living Constitution" concept would seem to require historical evidence to support his assertions regarding the supposed import of abstract constitutional language. For Raoul Berger argues, in sharp contrast to Dworkin, that the 'terms, 'equal protection' and 'due process,' illuminated by clear history, are neither 'vague' nor 'ambiguous." These terms, he believes, are vague only to those who forget (or choose to ignore) that due process and equal protection were short hand phrases for specific legal ideas that were widely accepted at the time of the ratification of the Fourteenth Amendment. ${ }^{26}$ In the absence of historical evidence that would resolve this controversy, Dworkin would have been on stronger ground had he contended simply that 
Brown's universally recognized moral authority renders less imperative the need to reconcile the "living Constitution" concept with originalist premises.

\section{Originalist Icon?}

An Effort to Claim Brown.

Perhaps the most telling indication of Brown's significance in the debate over the "living Constitution" concept is the efforts of certain originalists to reconcile the decision with the intentions of the framers of the Fourteenth Amendment, this in spite of widespread agreement among legal scholars that such a feat is not possible. ${ }^{27}$ In an attempt to demonstrate that Brown is more susceptible to originalist justification than the conventional wisdom suggests, Michael McConnell focuses upon the behavior of Congress in the years immediately following ratification of the Fourteenth Amendment in 1868. ${ }^{28}$ Congressional deliberations through the mid-1870's afford much insight into the original understanding of the Fourteenth Amendment, he believes, because they "were conducted in explicitly constitutional terms by Congresses charged with enforcing the new Amendment." McConnell suggests that, "[b]etween 1870 and 1875, both houses of Congress voted repeatedly, by large margins, in favor of legislation premised on the theory that de jure segregation of the public schools is unconstitutional." He concedes that these desegregation bills never became law, but emphasizes that, "for procedural reasons, a two-thirds majority of the House of Representatives was required for final passage." That majorities of both houses of Congress favored such legislation - and that Congress managed to pass laws "prohibiting segregation of inns, theaters, railroads, and other common carriers," while "reject[ing] legislation that would have countenanced segregated education on a separate-but-equal basis" - leads McConnell to conclude that an originalist approach was available to the Court in Brown. The decision, he implies, should no longer serve as the prime symbol of the moral superiority of the "living Constitution" concept. $^{29}$

The jurisprudential stakes being fairly high, scholars have subjected McConnell's thesis to careful scrutiny and pointed criticism. Michael Klarman argues that McConnell 
does not demonstrate convincingly that members of Congress in the first half of the 1870 's voted for school desegregation, as opposed to voting merely for a prohibition of the exclusion of blacks from public education. He also takes issue with McConnell's assumption "that the meaning of the Fourteenth Amendment reposes in the intentions of its congressional drafters, rather than in those of its state legislative ratifiers (or, of either's constituents, manifesting their preferences at the polls)." More fundamentally, Klarman questions the relevance of evidence of the intentions of congressmen in the years following the ratification of the Fourteenth Amendment. Klarman raises "the possibility that civil rights sentiment changed dramatically between 1866 and 1872-74 and thus that the congressional debates...[of the early 1870's] might constitute unreliable evidence of what congressmen intended when they drafted the Fourteenth Amendment." Indeed, Klarman maintains that evidence regarding progressive opinion on racial matters in the early 1870's indicates just such a shift in sentiment. This result stands to reason, he argues. For, when one considers "the political and social context in which the Fourteenth Amendment was drafted and ratified," it appears "inconceivable that most indeed even very many - Americans in 1866-68 would have endorsed a constitutional amendment to forbid public school segregation." 30

The vulnerability of McConnell's historical argument is underscored by the fact that, Earl Maltz, a fellow originalist, provides a similar critique of McConnell's thesis. Like Klarman, Maltz supports the historical arguments of the segregationists in Brown and concludes that "Brown cannot be defended by reference to the original understanding." 31

\section{An Alternative Tack.}

Robert Bork suggests an alternative method of reconciling Brown with originalism. Unlike McConnell, he concedes that "those who ratified the [fourteenth] amendment did not think it outlawed segregated education or segregation in any aspect of life." $\mathrm{He}$ nevertheless believes that "the result in Brown is consistent with, indeed is compelled by, the original understanding of the fourteenth amendment's equal protection clause." By way of explanation, he contends that "[t]he [originalist's] search is not for a subjective 
intention"; rather, this method of constitutional interpretation involves the discovery of the "public understanding" that prevailed when the constitutional provision at issue was ratified. With regard to the equal protection clause, Bork argues that "[t]he text itself demonstrates that...equality under law was the primary goal." While "the ratifiers probably assumed that segregation was consistent with equality[,]...they were not addressing segregation." After all, "[s]egregation is not even mentioned in the clause." When Brown reached the Court, he notes, "it had been apparent for some time that segregation rarely if ever produced equality.... Since equality and segregation were mutually inconsistent, though the ratifiers did not understand that, both could not be honored." The Court had little choice but to declare segregation unconstitutional in order to stop the "[e]ndless litigation" over the quality of separate facilities, litigation that placed an enormous "burden on the courts" with no hope of "produc[ing] the equality the Constitution promised." 32

The obvious problem with Bork's argument is that, in regarding the equal protection clause as an abstract principle that enables judges to consider changed circumstances, his characterization of originalism appears no different from the "living Constitution" concept that he abhors. (This is to say nothing about the question of the historical legitimacy of this method of constitutional interpretation, which should be of much importance to a self-described originalist such as Bork.) ${ }^{33}$ Bork's repudiation of the notion of a "living Constitution" seems peculiar in view of his belief that "Brown $v$. Board of Education was... an example of the Court applying an old principle according to a new understanding of a social situation." Bork follows this observation with a declaration that may as well have come from the pen of Ronald Dworkin: "A judge who refuses to see new threats to an established constitutional value, and hence provides a crabbed interpretation that robs a provision of its full, fair, and reasonable meaning, fails in his judicial duty." 34

Bork does suggest, in contrast to "living Constitution" proponents, that, in "order to avoid lawlessness, the [abstract] principles a judge applies must...be neutrally derived and defined [as well as applied]"; and he adds that judges can only accomplish this task through fidelity to "the original understanding [which] is the only legitimate basis for a constitutional decision." 35 As Dworkin notes, however, once Bork abandons an 
interpretive model that links constitutional meaning to the specific intentions of the framers, "then he has nothing left to which he can tether an opinion of what they wanted, except the exceedingly abstract language they used." 36 Bork's defense of Brown, in short, "is more typical of the constitutional methodology [he] criticizes than it is of his own professed originalist methodology." That the latter judgment comes from the pen of McConnell, a fellow originalist, should lead one to hesitate before dismissing Dworkin's criticism of Bork as ideologically inspired. ${ }^{37}$

\section{Originalism Notwithstanding Brown.}

In contrast to Bork and McConnell, Maltz emphasizes that to concede the irreconcilability between Brown and the original intentions behind the Fourteenth Amendment (which he believes candor requires) is not to concede the indefensibility of originalism as a method of constitutional interpretation. The desegregation decision, he insists, "cannot be considered in isolation... The question is whether on balance, nonoriginalist activism has been or is likely to be a benefit to society." In other words, while Brown may well reflect the benefits of non-originalist decision-making or the "living Constitution" concept, "Dred Scott v. Sandford [in which the Court stated in 1856 that Congress had no authority to prohibit slavery in federal territories, and that descendants of slaves could never become citizens of the United States] just as surely reflects its dangers." Consideration of this and other notorious rulings, in which "the Court distorted history to make it seem that the decision was consistent with the original understanding," raises considerable doubt about "the institutional competence of the Court to deal with questions of profound moral and political significance." Rather than regard Brown as typical of the quality of non-originalist decision-making, Maltz suggests, we should consider the possibility that "[t]he case simply reflects a happy confluence of political circumstance that brought together a group of lawyers with a profound distaste for stateimposed racial segregation." And, if judges "freed from the constraints of originalism" are more likely to "express policies that remain controversial or are universally viewed as disastrous" than to render decisions "like Brown...[, which] clearly changed America for the better," then the morally responsible position for legal scholars is to discourage 
judicial reference to a theory of judicial review that spawned Dred Scott even though that theory also begot Brown. ${ }^{38}$

Dworkin concedes the point that "judges may make the wrong decisions." But, unwilling to cede the moral authority that Brown lends to the "living Constitution" concept, he is quick to suggest that "[w]e must not exaggerate the danger." On balance, he believes, the risk that constitutional decision-making unconnected to the intentions of the framers will produce ethical abominations (on the order of Dred Scott) over enlightened rulings (like Brown) is substantially less than the possibility that majoritarian institutions will produce laws that fail to consider adequately the rights of minorities. To limit judicial recognition of rights to those examples that the framers of a constitutional provision specifically considered is, in most cases involving the claims of minorities, "to make the majority judge in its own cause." To Dworkin, "[this] seems inconsistent and unjust." Furthermore, even if the Court renders a decision that violates the ethical sense of a majority of citizens, "[t]ruly unpopular decisions will be eroded because public compliances will be grudging [i.e., the federal judiciary has authority over neither sword nor purse]... and because old judges will die or retire and be replaced by new judges appointed because they agree with a President who has been elected by the people." 39

Like Maltz, and in contrast to Dworkin, Antonin Scalia believes that an objective assessment of the respective advantages and drawbacks of originalism and nonoriginalism demonstrates the superiority of the former interpretive method over the latter. But Scalia reinforces Maltz's analysis by borrowing Dworkin's argumentative technique of minimizing the deficiencies of his favored theory of judicial review. Scalia's contribution to the debate takes the form of a confession "that in a crunch [he] may prove a faint-hearted originalist." In other words, while originalism "[in] its undiluted form...is medicine that seems too strong to swallow," judges are unlikely to apply this interpretive method rigorously. Rather, "[t]he inevitable tendency of judges to think that the law is what they would like it to be will...cause most errors in judicial historiography to be made in the direction of projecting upon the age of 1789 [or 1868] current, modern values - so that as applied, even as applied in the best of faith, originalism will...end up as 
something of a compromise." Scalia muses: "Perhaps [this is] not a bad characteristic for a constitutional theory." 40

One might expect Scalia to have argued that the Brown decision itself suggests that judges are unlikely to adhere to the more repellent consequences of originalism. Such a stratagem would have been in keeping with the efforts of scholars on both sides of the debate over the "living Constitution" concept to invoke that decision. His failure to mention Brown, however, may well reflect an understanding that a reference to the decision to demonstrate the unlikelihood of the worst aspects of originalism sounds rather hollow in comparison to the rhetoric of non-originalists who claim Brown as an emblem of the promise of their method of constitutional interpretation.

\section{Brown and the Color-Blindness Principle}

Precedential Support for a Ban on All Racial Categories?

Early Interpretations of Brown.

While virtually all critics of the "living Constitution" concept acknowledge the moral authority of Brown, many apparently do not believe that, in order to challenge at least the equal protection rulings of the Warren and Burger Courts, it is necessary to attempt to reconcile the decision with the framers' intentions or, alternatively, to conduct comparative cost-benefit analyses of originalist and non-originalist interpretive methods. For these scholars question whether these rulings are even consistent with the principle and spirit of the desegregation decision. Specifically, they maintain that the Court's receptiveness to "benign" or "benevolent" racial classifications contravenes Brown's promise of color-blind justice.

The view that Brown prohibits racial classifications of any sort was neither late in coming nor confined to the nation's law reviews (nor even to "living Constitution" opponents). Indeed, shortly after the Court rendered Brown, the editors of the New York Times drew a comparison between Chief Justice Earl Warren's opinion for the Court and 
the dissent of Justice Harlan in the notorious case, Plessy v. Ferguson. ${ }^{41}$ One will recall that Harlan declared famously, albeit futilely: "Our Constitution is color-blind, and neither knows nor tolerates classes among citizens." 42 The Times editorial intoned: "It is fifty-eight years since the Supreme Court, with Justice Harlan dissenting, established the doctrine of 'separate but equal'.... It is forty-three years since John Marshall Harlan passed from this earth. Now the words he used in his lonely dissent in an 8-to-1 decision in the case of Plessy v. Ferguson in a 1896 have become a part of the law of the land." The editors believed "there was not one word in Chief Justice Warren's opinion that was inconsistent with the earlier views of Justice Harlan. This is an instance in which the voice crying in the wilderness finally becomes the expression of a people's will and in which justice overtakes and thrusts aside a timorous expediency."43

Such a reading of Brown, however, was not apparent to all reasonable minds in the 1950s. Indeed, in what would become a famous essay on the concept of judging, Herbert Wechsler pointed to the decision's lack of guidance concerning "benign" racial classifications as evidence of its unprincipled nature. Wechsler conceded that the subsequent per curiam decisions, in which the Court invalidated state-maintained segregated parks, beaches and bath houses, golf courses, and public transportation, ${ }^{44}$ might indicate that the justices believed "that the fourteenth amendment forbids all racial lines in legislation." But he also argued that, because the Court provided no explanations for its rulings in these cases, one "do[es] not know" and "cannot know" whether they forbade all state-enforced racial classifications or approved only the immediate results in the lower courts, "and, if the latter, on what ground." To emphasize the tenuousness of any link between Brown and the color-blindness principle, Wechsler invoked Learned Hand, who observed that, in Warren's opinion for the Court, "the separate-but-equal formula [of Plessy v. Ferguson] was not [even] overruled 'in form,"' because the Chief Justice limited his analysis to the negative effects that segregation has upon black school children. ${ }^{45}$

Alexander Bickel, while not an opponent of the "living Constitution" concept, ${ }^{46}$ provided an argument that he thought demonstrated the constitutional illicitness of remedial racial classifications and, therefore, established a necessary connection between Brown and the color-blindness principle. Writing well before the Burger (or even the 
Warren) Court dealt with this issue, he explained: "That there should be no distinctions of race ordained by the state - that is a principle"; this position is "an intellectually coherent statement of the reason for a result which in like cases will produce a like result, whether or not it is immediately agreeable or expedient." By contrast, the alternative explanation of Brown's import - that the decision held "there should be no distinctions of race ordained by the state except when their consequences may be that the racial prejudices of the people are mitigated in the long run" - suggests that Brown was informed "[by anything but] a principled rule of behavior." For this alternative interpretation of the ruling "is the statement of a goal whose attainment will call for a great many prudential judgments, aimed at a goal, to be sure, but not proceeding immediately from principle." Put another way, "[t]he question of which arrangement, based on the invidious criterion of race, is consistent with ultimate attainment of the goal will most often be answerable only by a doubtful and variable judgment of expediency." $" 47$

In elaborating upon the empirical concerns that informed his belief in unprincipled nature of "benign" racial classifications, Bickel revealed that his position rested upon a particular assessment of social fact, as opposed to a belief in the superiority of legislatures over courts to ascertain the relative social status of racial groups. "What may be hoped for from the benevolent quota," Bickel suggested, "is that association of the races - limited to begin with - will allay the fears and other irrationalities on which white prejudice is nurtured," "[e]specially in the young." But he declared: "[I]t cannot be denied that in its objective operation, a benevolent quota is as invidious as straight-out segregation." For "most Negroes will be ["denied their freedom to associate"], and the others will be allowed to associate only on the basis of special arrangements that proclaim their apartness and hence inferiority." In short, though the intentions behind "benevolent" racial classifications may be laudable, these racial groupings "may provide as much nourishment for prejudice as a complete prohibition against association of the races." As a result of his reading of social facts regarding race, Bickel concluded that only "the absolute principle that race is not an allowable criterion for legislative [as well as judicial] classification" can properly explain the Brown decision. ${ }^{48}$

\section{Indirect Evidence and Social Fact.}


Critics of the "living Constitution" concept, as self-described defenders of the rule of law, are not content to allow Brown's association with the color-blindness principle to rest upon interpretations of social fact alone. They thus marshal indirect evidence that supposedly demonstrates that the Warren Court justices intended initially to establish such a link. (The justices' concerns over southern reactions to a ruling that precluded all forms of segregation, the implicit argument runs, led them to avoid making explicit the color-blindness rationale of the decision.) Philip Kurland, whose analysis of Brown's import appeared after the Warren and Burger Courts proved receptive to "benign" racial classifications, points to the opinion in the federal segregation case, Bolling v. Sharpe. ${ }^{49}$ There, he notes, the Court stated that " [c]lassifications based solely upon race must be scrutinized with particular care, since they are contrary to our traditions and hence constitutionally suspect" " and held that "“[s]egregation in public education is not reasonably related to any proper governmental objective."” Kurland muses: "How much better it might have been for the Court to have made Brown the tail to the Bolling kite, rather than vice versa." 50

To support his contention that Bolling (and Brown) "damn[ed] the use of race as a basis for legislative classification except in the nonexistent case of a reasonable connection between race and a legitimate governmental objective," Kurland emphasizes that the Warren Court's early decisions regarding the implementation of Brown were all "premised on the concept that the constitutional evil of school segregation inhered in its classification by race. The ultimate measure of racial balance was still to be discovered or, at least, acknowledged by the Supreme Court." In Goss v. Board of Education of Knoxville, Tennessee,${ }^{51}$ for example, the Court assumed the validity of a desegregation plan that provided for rezoning of schools without regard to race, but struck down a provision that permitted voluntary transfers from any school in which a student was in a minority to a school where he would be in the majority. Kurland concedes that "there was emphasis [in the Court's opinion] on the fact that the one-way transfer provision would be conducive to segregation." But he insists that "the Court's primary emphasis focused on the impropriety of the use by government of a racial classification as the basis for transfers." 52 
Kurland suggests that the Court's use of the color-blindness principle should not be surprising, since the justices merely responded to the plaintiffs in Brown. "[I]n the beginning," he observes, the plaintiffs' demands were for nothing more than "the elimination of race as a classification for the assignment of pupils to schools." One need only examine Thurgood Marshall's comments during oral argument to see that "the general position of the appellants throughout the Brown litigation [was] that race was irrelevant to any legitimate governmental objective." When Marshall discussed the appropriate method for assigning students to schools, he stated explicitly that "lines...drawn on the basis of color ...would violate the injunction [against racial discrimination]. [But if] the lines are drawn on a natural basis, without regard to race or color, then...nobody would have any complaint.",53

William Bradford Reynolds reinforces Kurland's point by observing that, like Thurgood Marshall in the 1950s, the leaders of the civil rights movement of the 1960s were "passionately committed to the colorblind principle of equal opportunity for each individual." Indeed, one can see that "[p]referential treatment based on race was intolerable to them, regardless of the purpose," when one considers the statements of Roy Wilkins during congressional consideration of the Civil Rights Act of 1964. The Executive Director of the NAACP, Reynolds emphasizes, stated "unabashedly" that the NAACP " "believe[s] the quota system is unfair whether it is used for [blacks] or against [blacks].”" “'[P]eople,"” Wilkins declared, "“ought to be hired because of their ability, irrespective of their color." 54

Reynolds regards these statements as evidence of "a broad recognition" as late as the 1960s - "a national consensus" of which the Court was part - "that racial classifications are wrong - morally wrong - and ought not to be tolerated in any form or for any reason." This national consensus, he believes, was stated most clearly in the Brown decision, which "acknowledged with eloquent simplicity that the equal protection clause requires governmental race neutrality in all public activities."55 No doubt, Reynolds would agree with Kurland's contention that "[it] was [the Court's acceptance of] this notion of forbidding the states to classify students by race that afforded strength to the Brown and Bolling decisions"; by embracing the color-blindness principle, the 
Court not only undid the tragedy of Plessy but "obliterat[ed]...the racial classification made by Dred Scott" as well. ${ }^{56}$

Unfortunately, Reynolds laments, the commitment of civil rights leaders to equality of opportunity gradually "evolve[d] [during the 1970s] into an insistence upon equality of results for groups." In response, the Court "blurred" the "individual-oriented concept of racial neutrality [at the center of Brown]...into the group-oriented concept of racial balance, on the representation that the former could not be fully realized unless the latter was achieved." Like Bickel, he anticipates that racial polarization will be the unintended consequence of "the use of racial preferences - whether in the form of quotas, goals, or any other numerical device - to correct what is perceived as an 'imbalance' in our schools, our neighborhoods, our work places, or our elected bodies." Race-conscious policies, he warns, "[encourage] us to stereotype our fellow human beings"; to "view their advancements, not as hard-won achievements, but as conferred benefits"; and "to look upon people as possessors of racial characteristics, not as the unique individuals who they are." $" 57$

As a critic of the "living Constitution" concept, Kurland traces the Court's acceptance of race-conscious policies to the interpretive method that the justices employed in order to achieve the results of the desegregation cases. The Court's willingness to secure "the contribution of Brown and Bolling" through a "[d]istortion of 'original meaning"" - to "[abandon] the search for the framers' intent" and "[choose] instead to write a Constitution for our times" - reflected an inclination on the part of the justices to disregard legal constraints of all sorts, including the principle of the Brown decision itself. When, in the racial balance and busing cases, the Court "[stood] the decisions from Brown through [the early implementation rulings] on their heads," Kurland argues, the justices "committed a mischief that may take longer to cure than the various uses of race by American governments to deny black-skinned persons admission to the American polity." "To use race as a class [even for beneficent purposes]," he explains, "is necessarily to assert that there are fundamental differences between races and not merely the named superficial ones." And, like Bickel and Reynolds, he suggests that the Court would exacerbate rather than "eradicate racism by adopting its fundamental 
premise that there are differences between races that justify distinct treatment by the law." The decisions in which the Court placed its imprimatur upon "benevolent" racial classifications, in short, “turn back the clock - back beyond Plessy's 1896, back beyond the fourteenth amendment's 1868, back to 1857 and Chief Justice Taney's opinion in Dred Scott v. Sandford, which was indeed based on the proposition that skin color carried with it all sorts of other attributes - physical, moral, intellectual - which distinguished all black persons from all white persons."

One might be tempted to conclude that Kurland's negative assessment of social facts relating to the Court's use of "benign" racial classifications in the enforcement of Brown are of secondary importance to a belief in the institutional competence of executive and legislative bodies relative to the judiciary. For originalist criticism of the "living Constitution" concept implies the need for judicial deference to democratic decision-making, absent a clear intent on the part of the framers to prohibit the type of governmental activity at issue. After criticizing the Court's lack of deference to state officials in the busing cases, however, Kurland identifies as particularly objectionable "the premise of Mr. Justice Blackmun in his separate opinion in [Regents of the University of California v.] Bakke, that having used racial categories to justify burdens on blacks, it is not inappropriate to use racial categories to confer benefits upon them." Blackmun, one should note, made this argument in support of the university's decision to consider racial criteria as part of its admissions process and against the view that such a policy violates the concept of equal protection of the laws. And Kurland does not suggest that the basis of his objection to Blackmun's premise (and of his apparent belief in the unconstitutionality of affirmative action measures) is the conviction that "benevolent" racial categories are contrary to the intentions of the framers of the Fourteenth Amendment. Kurland, then, appears less concerned that the desegregation decision initiated an "expansive neo-natural law syndrome that allows the Justices to act not merely as interpreters of the Constitution, but as its creators" than that the Court ultimately embraced a vision of social reality that did not comport with the view of social fact implicit in the color-blindness principle that Brown (supposedly) enunciated. ${ }^{59}$

The Framers (Again) and Social Fact. 
William Van Alstyne would take issue with the suggestion that the opposition of originalists to affirmative action measures rests solely upon a particular interpretation of social fact and a belief that "benevolent" racial categories are inconsistent with Brown. Indeed, he regards affirmative action policies as a product of the marked willingness of "living Constitution" proponents to disregard the clear commands of the Constitution. "The observation ["that the Constitution is a 'living' document"]," he charges, "is nearly always offered as a prelude for urging the Supreme Court to manipulate or disregard some rather unequivocal part of that document." But Van Alstyne's proof of the inconsistency between constitutional intent and legislative use of "benign" racial classifications is limited to the statement that "there is nothing in the Constitution that licenses the national government to establish racial shares, to legitimate measuring the worth of people by their race, or to tender entitlements by race."60 The burden clearly rests with him to provide a more convincing argument, since his assertion runs contrary to the view of most originalists that broad interpretations of national powers are entirely consistent with the framers' intentions. ${ }^{61}$

While Van Alstyne's analysis of the intentions of the framers of the Fourteenth Amendment is not quite as brief as his treatment of the constitutional framers, he is not as certain that the history behind the equal protection clause supports his opposition to "benign" racial classifications. When Justice Harlan enunciated the color-blindness principle in his Plessy dissent, Van Alstyne concedes, "[he] was prepared to read into the Civil War amendments what was, to be sure, neither explicitly provided by their terms nor compelled by their compromised legislative history." But Van Alstyne argues that Harlan "put his finger on the lessons of his own contemporary history" - that the use of race to determine status, settle entitlements, assign worth, and measure legal rights "had been iniquitous from the very beginning" and had "subsequently proved to be a disaster for the entire country." Harlan was thus justified in "believ[ing] [that] the enactment of the Civil War amendments should...be construed by the Court as altogether disallowing [racial classifications]." 62

In contrast to Van Alstyne, Michael Klarman (among others) argues that the history of the Fourteenth Amendment regarding the matter of "benevolent" racial 
classifications is neither inconclusive nor supportive of the color-blindness principle. "[T]he same thirty-ninth Congress that wrote the fourteenth amendment," Klarman notes, "contemporaneously enacted race-conscious statutory schemes designed to benefit southern freedmen." And he observes that "arguments regarding race-conscious benefit programs bandied about in the Reconstruction Congress were strikingly similar to those voiced in today's affirmative action debate; and precisely the same men who drafted the fourteenth amendment rejected the arguments against race-conscious legislation."63

Laurence Tribe notes that originalists might respond to this argument with the point that "those pieces of nineteenth century legislation [that employed remedial racial classifications] were at least partially, if not exclusively, designed to assist actual victims of slavery." Still, Tribe contends that, since "the Framers of the Fourteenth Amendment...did not intend...to outlaw racially segregated public schools," "[it] involves quite a stretch...to take their original intentions as an argument that all racespecific distinctions, even those designed to facilitate practical equality, are either automatically or presumptively unconstitutional." 64 Originalist defenders of the colorblindness principle who seek a response to Tribe's argument would do well to look beyond Robert Bork's cavalier assurance that "the relevant constitutional and statutory law, properly interpreted, supports [those who oppose race-conscious policies]." 65

In comparison to their historical critiques of affirmative action, Van Alstyne's and Bork's discussions of the negative effects of such policies are striking in their detail. Bork emphasizes the prospect that increased racial tensions will be the ironic result of well-intentioned, race-conscious policies. He believes "racial resentments are certain to be inflamed" when "non-whites who have not suffered discrimination are preferred to whites who have not inflicted discrimination." And he anticipates that, over time, racial animosity will "grow more acute...because the question of race and ethnicity is no longer simply a black-white issue." Conflicts among minority groups, he maintains, will be as severe as those between whites and non-whites. For, already, "[w]e...see competition for group entitlements among whites of European ancestry, blacks, Hispanics and Asians."66 No doubt, Bork would accede to Van Alstyne's statement that "[w]e shall not now see racism disappear by employing its own ways of classifying people and of measuring their rights. $" 67$ 
Van Alstyne refers to another "obvious practical reason" for judges to take "a very consistent, very firm position" against race-conscious programs:

\begin{abstract}
We have had three hundred years of national experience to notice that whenever race has been an admissible criterion of governmental action, its licitness left people in public office without shelter against the organized efforts of those who would demand that they have a duty to act on that licitness: that they carry the alleged 'merits' of race into appropriate legislation. We are also not without example of the inevitable necessity, the instant such regulation or allocation by race has been understood to be acceptable to the Supreme Court, for the Court ultimately to have to decide several other things as well. Among the more obvious issues, as additional groups, people, agencies, and parties are inevitably drawn in, are these: which races, how much to each race, by what test is each of us assigned 'our' race ${ }^{68}$
\end{abstract}

Van Alstyne believes that "[t]he odiousness of these issues will be no less should the Court now reopen this governmental license than it was some years ago" in "the Plessy v. Ferguson experiments in racial designation and racial allocation." 69

In view of the strength of Van Alstyne's convictions regarding the harms of raceconscious policies and the weakness of his historical arguments, one should not be surprised that he, like Kurland, strives to link Brown to the color-blindness concept. To "[k]eep...faith with the lesson of the great [racial equality] decisions of the Supreme Court," he maintains, is to recognize "the novelty...in the explication of arguments to relicense governmental discrimination." As proof of Brown's connection to the colorblindness principle, Van Alstyne, like Kurland, suggests that the Court's post-Brown rulings indicated that the constitutionally problematic nature of segregation inhered in the practice of classification by race per se. Unlike Kurland, however, he goes so far as to suggest that even the busing decisions "convey this same message." The "reasonably discerning" individual, he argues, understands that, "in instances involving highly controversial judicial decrees that paired racially identifiable schools, redrafted attendance lines, or mandated busing," "the fulcrum of judicial leverage was an existing 
governmental race line, which the particular judicial order sought to remove." In other words, "[t]he object was...to disestablish particular, existing uses of race, not to establish new ones.",70

\section{$\underline{\text { Some Obvious Problems }}$}

Contrary Evidence.

Not all originalist critics of the Supreme Court's receptiveness to race-conscious policies think that Brown affords a basis upon which to critique the relevant decisions. Indeed, Ralph Rossum, in pointing to basic considerations that render problematic any effort to link Brown with the color-blindness principle, appears to be concerned with avoiding the damage that a disingenuous argument would cause the originalist position. Extending the logic of Wechler's criticism of the color-blind interpretation of Brown, ${ }^{71}$ Rossum notes that "Chief Justice Warren's opinion never even refers to Harlan's [Plessy] dissent." Any attempt to explain Warren's oversight by emphasizing his effort to adopt a nonaccusatory approach that did not immediately call into question the entire southern way of life (especially the South's fear of miscegenation) founders on the fact that, in subsequent cases, the Court never explicitly embraced the color-blindness principle. Rossum declares: “Justice Brennan's words in his Bakke concurrence are all too true[:] 'The position that such factors [as color or creed, birth or status] must be "constitutionally an irrelevance"...summed up by the shorthand phrase "our Constitution is color-blind,"...has never been adopted by this Court as the proper meaning of the Equal Protection Clause. Indeed, we have expressly rejected this proposition on a number of occasions.",72

Rossum might have added that Kurland's effort to portray Warren's opinion in Bolling v. Sharpe as evidence of the Court's acceptance of the color-blindness principle is also open to an obvious criticism. ${ }^{73}$ To contend, as Warren did, that "[c]lassifications based solely upon race must be scrutinized with particular care, since they are contrary to our traditions and hence constitutionally suspect," is necessarily to concede that racial classifications are not necessarily forbidden. Put another way, in suggesting that racial classifications might be appropriate in certain circumstances, Warren necessarily rejected the color-blindness principle. ${ }^{74}$ 
Both Rossum and Gary McDowell emphasize a final consideration that works against efforts to link Brown with the color-blindness principle - Warren's focus upon racial groups, as opposed to individual litigants. Echoing Reynolds, Rossum notes that the color-blindness principle holds "that equal protection of the law is guaranteed to every person on an individual basis and not on the basis or racial classifications or group identification." In contrast to Reynolds, however, he observes that, "in Brown, since [the Court] was now persuaded by modern psychological authority that segregation did stigmatize blacks, it...saw no need to concern itself with the individual plaintiffs and with whether they had personally experienced psychological harm from segregation. It was enough that segregated schools 'may affect' the 'hearts and minds' of schoolchildren 'in a way unlikely ever to be undone." $" 75$ Similarly, McDowell points out that Brown was based upon the understanding that "all blacks, solely on the basis of their race, had suffered alike, whether they knew it or not"; the individual plaintiffs "had been replaced by an aggrieved social class." ${ }^{, 76}$ Indeed, Rossum observes that, under the color-blindness concept, there is "no need for the plaintiff seeking vindication of his constitutional rights to demonstrate first that he had suffered some harm"; the constitutional violation inheres in the classification itself. ${ }^{77}$

This portion of Rossum's and McDowell's critique of scholarly efforts to link Brown with the color-blindness concept, one should note, runs contrary to the conventional view that the Court's discussion of the harms that segregation inflicted upon black school children was not the actual basis of the decision. ${ }^{78}$ Even if one assumes that the Court's acknowledgment of the oppressiveness of segregation represented the true (albeit, unstated) basis of Brown, however, McDowell notes that the Court's rejection of the color-blindness concept was also apparent in its remedy for the constitutional violation at issue. He observes that "the relief was not to be applicable to the plaintiffs alone, or even to all those 'similarly situated' who also felt deprived; it was to extend to all blacks regardless of their particular social, economic, or educational situations."79 Reflecting upon the injustice of the Court's race-conscious approach to resolving the controversy in Brown, Rossum adds: "[I]n its implementation decision..., the Court felt free to adopt an 'all deliberate speed' formula that provided the apparently successful 
plaintiff...with "no more than a promise that, some time in the indefinite future, other people would be given the rights which the Court said he had.'",80

In sharp contrast to their fellow originalists, then, McDowell and Rossum conclude that the Court's later decisions, which accepted the constitutional legitimacy of "benign" racial classifications, were "merely the fulfillment of the logic of [Brown]" (to use McDowell's words) rather than a departure from its promise. McDowell argues that the Court's later "affirmative demand for racial integration" in public schools (a demand that resulted in the Court's formulation of "public policies for which it lacks not only the institutional capacity but, more important, the constitutional legitimacy") was entirely consistent with Brown's "primary concern [with] the social class or group instead of the individual." 81 Rossum maintains that "[t]he Court's...emphasis [in Brown] on group interests over individual rights" is also apparent "in Bakke, [where] it upheld ameliorative racial preference... because such preference is intended not to stigmatize blacks as a group but rather to benefit them." In this and other racial preference cases, he laments, the Court "created new resentments, new turfs to be protected"; it "pitted one race against another in what may, without exaggeration, be called the paradigmatic class struggle." 82

\section{Invoking an Alternative Symbol.}

In view of the problematic nature of the efforts of most originalists to criticize recent Supreme Court decisions by invoking the moral authority of Brown, Rossum attempts to strengthen his critique of the Warren and Burger Courts by linking the desegregation decision and its supposed progeny with what is now universally regarded as the quintessential example of judicial abstraction in race cases - the reasoning of the Plessy majority. In Plessy, he notes, the Court "defined citizens in terms of their surroundings and their color." In so doing, the justices "pursued a contemporary parallel of feudal sociological jurisprudence that the American tradition has expressly sought to eradicate, not embrace." Put another way, they adopted a social vision that harked back to a time when a person's economic and social status determined the justice he would receive. Regrettably, in Brown and in later race cases, Rossum suggests, "the Court has operated 
in much the same way. It has first identified citizens in terms of their race and has then determined their rights (and whether these rights will be vindicated) on that basis." Rossum believes that " $[\mathrm{t}]$ his approach...disposes of the concept of citizenship altogether. No longer are men seen as citizens - in essence, as bearers of rights; rather,...they are viewed as supplicants - as petitioners for favors." 83

Rossum's strategy of attacking the moral authority of Brown may seem imprudent, given that the decision, whatever rationale the Court employed, terminated an especially oppressive use of the law. One should note, however, that Rossum is able to invoke as support for his position Justice Harlan's Plessy dissent, a constitutional icon with standing second only to that of the desegregation decision itself. As important, from Rossum's perspective as an originalist, Harlan's dissent serves as a vehicle to illuminate the (supposed) consistency of the color-blindness principle with the intentions of the framers of the Constitution, if not the framers of the Fourteenth Amendment. Justice Harlan's color-blind approach to racial discrimination, he suggests, "was consistent with America's liberal tradition and its commitment to the welfare, rights, and responsibilities of the individual." What is more, "his approach was essentially related to the Constitution's solution to the most serious problem of republican government: majority tyranny." One of the principal remedies that the framers employed to cure this disease of republican government, Rossum explains, "was reliance on the operation and interaction of a multiplicity of interests present in the extensive republic they were establishing." And Harlan's approach to race - "to regard man as man," and not to pit one race against another - would have facilitated "the effective operation and interaction of the...multiplicity of interests." Such a policy would help to ensure that "the coalitions of minorities that form to act as majorities" are "temporary" and are "continuously replaced by newer coalitions made up of different combinations of interests." $\$ 4$

Rossum's discussion of the connection between the color-blindness principle and the framers' institutional remedies for majority oppression is emblematic of the political optimism implicit in the pessimistic assessment of social facts relating to race-conscious policies that originalist critics of such policies put forth. For the obverse of his view that such policies intensify racial animosity is his belief that an avoidance of racial 
classifications will promote racially moderate majorities, and that one's race does not determine one's social status in this country.

Even if one assumes that Kurland, Van Alstyne, and Bork, in contrast to Rossum, suggest no more than that color-blind policies prevent racial animosity from worsening, these scholars also exhibit a certain confidence in existing political arrangements. Implicit in their writings is the belief that the situation of African-Americans under the racial status quo is preferable to the hostility that is visited upon blacks when government attempts to compensate them for the injustices of the past.

\section{Brown and the Racial Subordination Principle}

\section{Precedential Support for "Benign" Racial Classifications?}

The Rehnquist Court and Non-Originalist Angst.

While originalist critics of the "living Constitution" concept see little to celebrate in the racial equality rulings of the Warren Court and find much that is objectionable in the Burger Court's decisions, they are heartened by other Burger Court rulings that evidence a "counter-current," or a change in tone and approach that carried into the decisions of the Rehnquist Court. ${ }^{85}$ In Milliken v. Bradley, ${ }^{86}$ for example, the Court, for the first time, refused to sanction a school desegregation remedy that the NAACP requested. In so doing, the justices prevented lower courts from countering racial imbalances that resulted when "white flight" to the suburbs exacerbated segregative practices in urban school districts. Specifically, Chief Justice Burger held for a narrow majority that lower courts cannot order inter-district busing as a remedy for segregation when no inter-district violation has occurred. Two years later, the Court rejected a district court desegregation plan that prohibited any school from having a majority of black students, and that required annual adjustments to maintain a specific racial balance. ${ }^{87}$

In the same year as the latter decision, the Burger Court also refused to extend to constitutional controversies the approach to discrimination that it had adopted in cases 
involving Title VII of the Civil Rights Act of $1964 .{ }^{88}$ In Washington v. Davis, ${ }^{89}$ the Court explicitly rejected the argument that evidence of a disproportionate racial impact is sufficient to show unconstitutional racial discrimination under an ostensibly neutral governmental practice. The Court ruled, instead, that "the basic equal protection principle" is "that the invidious quality of a law claimed to be racially discriminatory must ultimately be traced to a racially discriminatory purpose." 90

With regard to cases involving Title VII, the Rehnquist Court departed from the Burger Court's interpretation of this portion of the Civil Rights Act by shifting legal standards in favor of defendants. In Ward's Cove Packing Co. v. Antonio, ${ }^{91}$ the Court held that, when a specific employment practice has a disparate racial impact, the plaintiff must assume the ultimate burden of persuading a judge that this impact amounts to discrimination. ${ }^{92}$

That same year, the Rehnquist Court demonstrated a skepticism toward the constitutionality of race-conscious policies that originalists thought had been absent in the Burger Court's decisions. In Richmond v. J. A. Croson Co., ${ }^{93}$ the Court found that the city's Minority Business Utilization Plan, which established a set aside provision for minority contractors, violated the equal protection clause of the Fourteenth Amendment. Specifically, the six justice majority regarded as insufficient evidence of racial discrimination the fact that only $0.67 \%$ of contracts had gone to minority contractors in a city in which blacks comprised $50 \%$ of the population. While the Court did not invoke the color-blindness principle, it declared that "benevolent" racial classifications are suspect. And, since the Court had held previously that the mere existence of racial discrimination in American life is not a constitutionally sufficient reason for affirmative action remedies that give preference to members of minority groups, ${ }^{94}$ current equal protection doctrine would seem to require that, absent a showing of past discrimination against particular individuals, there exists no sufficiently compelling justification for such policies.

In response to these and other decisions, "living Constitution" proponents now emulate the strategy of the originalists by invoking Brown to criticize the Court's performance. They argue that the racial subordination principle, rather than the colorblindness concept, informed the ruling in Brown. More specifically, they contend that 
Brown reflects the view that government may not act to reinforce the subordinate status of any racial group but may employ racial classifications to aid the victims of discrimination. In this way, these scholars hope to provide a legal argument - one with substantial moral weight - that supports their discussions of the positive effects of remedial racial classifications and that reinforces their criticism of post-Brown rulings which implicitly deny the pervasiveness and subtlety of racism in society.

\section{Indirect Evidence and Social Fact.}

Laurence Tribe regards Brown as only the most significant of several legal considerations that reveal the baselessness of judicial hostility to race-conscious policies. In an argument that would appeal to critics of the Croson decision, he observes that, when the Court first declared that racial classifications are constitutionally suspect (in the Japanese relocation case of 1944), ${ }^{95}$ it "held that the point of strict scrutiny for racial classifications is to detect whether they reflect '[p]ressing public necessity' or merely 'racial antagonism." "Racial antagonism...," he emphasizes, "is hardly the motive of today’s set-aside programs." 96

Tribe questions whether even Justice Harlan's “justly famous [Plessy] dissent" supports increased judicial hostility toward race conscious policies. ${ }^{97}$ Those who quote Harlan's reference to a color-blind Constitution, he argues, should "consider the context" in which the justice made that statement: "[T]he color-blind ideal, it turns out, was only shorthand for the concept that the Fourteenth Amendment prevents our law from perpetuating white supremacy." And Tribe regards as "far-fetched" the notion "that this particular view is shared, automatically or presumptively, by race-specific minority set asides." 98

The Brown decision, in Tribe's view, also affords little support to judicial and scholarly proponents of the color-blindness principle. To suggest that Brown "says that, more than a century after the Civil War, all race distinctions must now be banned as inherently "unequal,", he argues, is to adopt a "sweeping and 'activist"" reading of the ruling. "On the face of it," he continues, "... a more modest, less radical and less strained interpretation" of Brown is that the decision merely "ban[ned] the use of law to subjugate 
a racial group." Rather than elaborate upon Brown's connection to a racial subordination principle, however, Tribe provides additional reasons why originalists should find the former interpretation of the ruling difficult to accept. "[A]bsent a textually or historically clear constitutional prohibition," he says, hostility toward the legislative use of remedial racial classifications "seems hard to square with [the originalists' usual call for] judicial deference to political majorities." 99

Ronald Dworkin provides a philosophical argument that supports Tribe's contention that the most natural reading of Brown is one that posits a connection between that decision and the racial subordination principle. In contrast to Bickel, ${ }^{100}$ Dworkin does not assume that considerations of social fact render the belief in the need for "benign" racial classifications unprincipled and, therefore, an inappropriate account of Brown's import. The expectation that legislative or administrative employment of remedial racial classifications "will exacerbate racial tension and so prolong discrimination, hatred, and violence," he contends, "is exactly the kind of complex, forward-looking calculation of policy that even a weakened, sensible form of passivism would leave to the judgment of elected officials or of executives appointed by and responsible to those officials." In Dworkin's view, "[t]he Supreme Court should not take that judgment of policy upon itself."101

Dworkin defends the view that the racial subordination principle provides the best explanation of the meaning of Brown by suggesting (again, in sharp contrast to Bickel) that the alternative reading of the decision - one based upon the color-blindness or "banned categories" theory - is "too arbitrary" to qualify as a principled interpretation. The color-blindness concept, he explains, "must be supported by some principled account of why the particular properties it bans are special, and the only principle available is that people must never be treated differently in virtue of properties beyond their control." One must reject this proposition because "[s]tatutes almost invariably draw lines along natural differences of geography and health and ability." And no one would suggest that legislatures are engaging in inappropriate behavior when "they subsidize workers who have by chance come to work in one industry or even [sic] firm rather than another," or when they "restrict licenses to drive or practice medicine to people with certain physical or mental abilities." In short, "if race were a banned category because people cannot 
choose their race, then intelligence, geographical background, and physical ability would have to be banned categories as well." Dworkin concludes that "[r]acial discrimination that disadvantages blacks is unjust, not because people cannot choose their race, but because that discrimination expresses prejudice." 102 Brown, then, necessarily reflects the understanding that legislatures may employ racial classifications, as long as they do not make an individual suffer "because he is a member of a group thought less worthy of respect, as a group, than other groups."103

Even if one assumes the cogency of Dworkin's discussion of the unprincipled nature of the color-blindness concept, his argument regarding the constitutional appropriateness of the racial subordination principle extends only to legislative or administrative uses of "benevolent" racial classifications. He cannot dismiss the concerns of Bickel and others (that remedial racial policies will exacerbate racial tension) by appealing to the notion of judicial deference when it is courts that make use of those policies. Indeed, Dworkin's defense of judicial deference to legislative and administrative uses of racial classifications - his contention that the Court should not make that policy judgment itself, as opposed to a statement that such policies are a necessary response to continuing racial injustice - implies a belief in the inability of courts to make factual determinations regarding the impact of such policies.

To the extent that Dworkin and other "living Constitution" proponents support court-ordered busing and racial quotas as equitable remedies for school segregation, ${ }^{104}$ they must accept a description of social reality that emphasizes the persistence and pervasiveness of racism. As Dworkin says in an alternative defense of race-conscious legislative and administrative policies: "American society is currently a racially conscious society; this is the inevitable and evident consequence of a history of slavery, repression, and prejudice. Black men and women, boys and girls, are not free to choose for themselves in what roles - or as members of which social groups - others will characterize them. They are black, and no other feature of personality or allegiance or ambition will so thoroughly influence how they will be perceived and treated by others, and the range and character of the lives that will be open to them." As for the possibility of altering this regrettable social situation, Dworkin argues that our nation "has not succeeded in reforming the racial consciousness of our society by racially neutral 
means." Indeed, "[t]he history of the campaign against racial injustice since 1954, when the Supreme Court decided Brown v. Board of Education, is a history in large part of failure." As a result, we are "obliged" (and, as Dworkin would have it, Brown encourages us) to consider race-conscious policies "with sympathy and an open mind." To those who find such policies distasteful, Dworkin asserts that such an objection "can only be for reasons that make the underlying social realities the programs attack more distasteful still." 105

\section{Brown as an Appeal to Social Fact.}

Alan Freeman, in contrast to his fellow proponents of the racial subordination principle (as well as proponents of the color-blindness principle), believes that scholars should abandon the "endless quest" for the principle at the heart of Brown. Like Wechsler, ${ }^{106}$ he regards as "fundamentally misguided" any effort to discern the principle behind the Court's "uncertain" and "elusive" rationale in that case. Freeman reasons that the decision's true contribution to constitutional law was to require that judges take "a close and direct look" at social facts regarding race. By "open[ing] a window that compelled white Americans to confront a particular and revolting social reality," he suggests, "Brown v. Board of Education clearly marked a break with the past" and "herald[ed] a period of great promise for improvement in [the] status of black Americans." 107

Unlike Dworkin, who appears unwilling to concede that his approach to racial equality cases depends at bottom upon his interpretation of social facts, Freeman clearly suggests that the "concrete historical experience" of African-Americans is sufficient to provide judges with guidance in contemporary racial equality cases. And, unlike Bickel, ${ }^{108}$ Freeman believes that a consideration of social facts precludes judicial reference to the color-blindness principle. The "harsh oppression, exclusion, compulsory reduced status, and derogatory cultural stereotyping" that blacks endured over the years, he observes, "left their mark in the form of identifiable consequences," including "residential segregation, inadequate education, overrepresentation in the lowest-status jobs, disproportionately low political power, and a disproportionate share of the least and worst of everything valued most in our materialistic society." The persistence of these 
conditions "in virtually identical form after antidiscrimination laws have prohibited racial discrimination" compels the conclusion that "the law has yet to be effective." Racism, he opines, apparently "persists at a much deeper level" than had been thought; we can now see that "it is an unconscious, culturally transmitted, and seemingly intractable feature of American life." If we test the law "by the only relevant measure of success - results" then judges will acknowledge the need to move beyond the ineffective legal remedies of the past. Specifically, they must regard a disproportionate racial impact as evidence of unconstitutional racial discrimination under an ostensibly neutral governmental practice, and they must deny challenges to the constitutionality of remedial racial classifications, which legislatures, administrators, or courts employ in their efforts to fulfill Brown's "promise of liberation from America's historical reality of caste-based oppression."109

Tragically, Freeman maintains, the Court's recent contributions to antidiscrimination law "seem to enshrine the principle of "unequal but irrelevant," rather than to deliver on "the glowing promise of Brown." The decisions in Ward's Cove and Croson, for example, "compel us to deny that starkly racial differences in status have anything to do with "discrimination." By indicating that "we cannot find violations of antidiscrimination law in objective social conditions, but only in the actions of identifiable perpetrators who have purposely and intentionally caused harm to identifiable victims," the Court substituted "abstract, timeless, and ahistorical" analysis for an examination of "the messy particularity of historical and current social reality." The color-blindness concept, which apparently informs the Court's hostility toward "efforts to improve conditions for historic victims of discrimination," "would be the appropriate rule [only] in a society that had totally eliminated racial discrimination, or, more likely, had never had such a problem at all." Judicial reference to that concept in our current social situation serves merely "to legitimize the persistence of rampant, racially identifiable inequality" by implying the existence of "individualistic equality of opportunity." 110

In a complementary argument, Morton Horwitz suggests that the plausibility of equality of opportunity depends upon the ability of defenders of this notion "to explain why an unusually large number of members of particular [racial] groups seem regularly to come out at the bottom" on numerous indices of social status. Persons "[u]nwilling to accept the disturbing reality or the anti-individualistic implications of a culture of group 
oppression and deprivation" are compelled to look to the efforts of certain social scientists "to find a correlation between intelligence and racial groups." "Without a genetic explanation of group deprivation," Horwitz declares, "the ideology of equality of opportunity is revealed as a fraud."111 (He might note that any claim to success in discovering such a correlation harks back to the more abhorrent arguments of segregationists. $)^{112}$ In the absence of an explanation for racial group differences in social status, he believes, judicial "den[ial] [of] the significance of group rights" amounts to "an egregious denial of reality as well as of justice." Like Freeman and Dworkin, then, Horwitz's reading of social facts regarding race leads him to conclude that Brown which "stirred up an ongoing jurisprudential debate over the nature and function of judicial review," while altering "our vision of race relations in this country" - should "stand as a barrier only to the use of racial classifications for the purpose of oppressing racial minorities." 113

Since Horwitz, Freeman, and Dworkin cannot expect at this point that legal scholars generally will regard this interpretation of social fact as self-evident, the efforts of other "living Constitution" proponents to establish a more convincing connection between Brown and the racial subordination principle assume added importance. David Strauss does not appear content to depend upon philosophical or empirical arguments to accomplish this task. In focusing upon evidence that provides clues as to the import of Brown, he acknowledges the "uncertain meaning" of the decision. Nevertheless, he stresses the significance of "[o]ne of the most famous sentences in Brown [which] emphasized that racial segregation of black children 'generates a feeling of inferiority as to their status in the community that may affect their hearts and minds in a way unlikely ever to be undone." He argues that the Court's reference to the damage done to the personalities of black children "suggests that the evil of racial segregation is the stigma it inflicts," while the justices' "emphasis on 'status in the community' might also reflect a [belief that racial classifications are illicit only if they serve to subordinate a racial group]." Either interpretation, he argues, supports the conclusion that "certain measures conventionally viewed as affirmative action" are constitutionally permissible. ${ }^{114}$

One might discount the former interpretive point because, as noted, it conflicts with the conventional view that the effects of segregation upon black children did not 
represent the actual basis of Brown. ${ }^{115}$ The latter point is also problematic as a defense of the racial subordination principle because the Court's language might suggest that governmental avoidance of all racial classifications is sufficient (or, as originalists would have it, necessary) to secure the status of blacks in the community.

Strauss attempts to establish an alternative link between Brown and the racial subordination principle through references to subsequent rulings. However, these references either do nothing to resolve the problem of indeterminacy, ${ }^{116}$ or they draw attention to rulings that Kurland identifies as departures from earlier post-Brown decisions that appear consistent with the color-blindness principle. ${ }^{117}$ While Strauss seems unaware of these shortcomings in his argument, he ultimately makes only the modest, although (to the minds of Kurland, Van Alstyne, and Reynolds) controversial, claim that the Court's racial equality rulings from Brown until Washington v. Davis "all [simply] left open the possibility that Brown would stand for a principle that mandated relatively far-reaching changes in society." 118 In view of the arguments of Rossum and McDowell, ${ }^{119}$ Strauss's intimation that the "tam[ing]" of Brown in Washington v. Davis amounted to nothing more the destruction of the desegregation decision's potential, as opposed to a distortion of its original meaning, seems surprisingly and, from the perspective of "living Constitution" proponents, regrettably timid.

"Significant Difficulties"

Contrary Evidence.

Not all defenders of the "living Constitution" concept who criticize the Supreme Court's increased hostility to the disparate racial impact test for discrimination and to remedial racial classifications believe that Brown affords a strong basis upon which to critique the relevant decisions. Richard Delgado and Jean Stefancic would be hard pressed to accept even the arguments of Rossum and McDowell regarding Brown's connection to the racial subordination principle. For (as Dworkin and Freeman demonstrate) ${ }^{120}$ acceptance of that principle implies a complicated understanding of social facts regarding race. And Delgado and Stefancic contend that the narrow scope of the legal process hinders the 
ability of judges to correct for the fact - and, presumably, even to ascertain - that "every social practice is part of an interlocking system of other practices, meanings, and interpretations, [and that] changing just one element (for example, school assignment rules) leaves the rest unchanged." Brown, they note, "set out to change just one element [of a system of social practices], leaving the force-field [of interconnected relationships] itself intact." 121 With good reason, the justices gave no indication that they understood the complexity of racism and the need for the racial subordination principle.

As to whether Brown at least left open the possibility for justices to adopt the racial subordination principle as the complicated nature of race relations became apparent, Delgado and Stefancic emphasize, instead, the unfortunate and predictable consequences of the Court's failure to assess blame to white America for the plight of black citizens. In view of the "forces that swallow social reform decisions like Brown" such as the desire of recalcitrant parties to construe disruptive rulings narrowly and the intransigence of "preexisting social practices" - the Court could not afford to deliver a muted opinion that encouraged or failed to confront such resistance. Brown, however, "remain[ed] silent on the issue of white responsibility" for the "long-standing predicament" of African-Americans and, thus, did little to prevent judicial retrenchment in the area of racial equality, let alone to secure the limited ruling of the case. ${ }^{122}$

Delgado and Stefancic do not blame Brown directly for either the lack of success in desegregating the nation's public schools or for the Court's recent hostility toward "benign" racial classifications. They stress that "[c]ourts are not in a position to engage in the kind of continuing dialogue that could in theory change meanings and practices" associated with segregation. And they characterize the recent move toward the colorblindness concept as "a retreat from the ringing words of Brown." But, suggesting that "Brown [w]as a startling, extraordinary decision" that "challenged and departed from current culture and orthodoxy," does not negate the implicit point that the Court contributed to "a backward drift in matters of race" because "the opinion failed to generalize" about the matter of white responsibility for black suffering. ${ }^{123}$ At the very least, Delgado and Stefancic indicate less of a sharp disconnection between Brown and the equal protection rulings of the Rehnquist Court than do either Strauss or Freeman. 
Delgado and Stefancic have ample reason not to emphasize the connection between Brown and the Rehnquist Court's recent equal protection decisions. For, like Rossum, ${ }^{124}$ they link the decisions that they find objectionable to the reasoning of the Plessy majority; unlike Rossum, however, they cannot, without great difficulty, claim the moral authority of Justice Harlan's Plessy dissent as a substitute for Brown's prestige. ${ }^{125}$ The Court's increased hostility to the disparate racial impact test for discrimination and to remedial racial classifications, they argue, "is reminiscent of the crabbed neutrality and unrealistic refusal to see discrimination that characterized Plessy." They find "[t]he most startling parallel" in the Croson decision's invalidation of Richmond's set aside provision for minority contractors. ${ }^{126}$ "The majority opinion," they observe, "found the [city] council's action a potential case of "simple racial politics." And "[a] concurring opinion went even further, warning that society should be watchful against those who might attempt to 'even the score' at the expense of whites." This decision and others, Delgado and Stefancic conclude, indicate that "we are rapidly returning to the regime of Plessy $v$. Ferguson's separate but equal doctrine" and to a "view of blacks as imposers and whiners because they desire to live in American society on the same terms as whites." Indeed, they go so far as to suggest that "American society, without the spur of Cold War competition or the need for minority labor or soldiers, is in serious danger of quietly, implicitly readopting a familiar standard from another era: Dred Scott v. Sandford, in which blacks and other minorities of color have no rights that white Americans are bound to respect." 127

\section{Brown's Blameworthiness.}

Louis Seidman, while equally disturbed by the equal protection rulings of the Rehnquist Court, does not attempt to link those decisions to the reasoning of Plessy or Dred Scott. Perhaps this fact contributes to his willingness to discuss the blameworthiness of Brown, not only for the Court's increased hostility to remedial racial classifications, but also for what he regards as a startling insensitivity to racism in society generally. But his primary reason for criticizing Brown in this manner is his conviction that efforts to establish a connection between that decision and the racial subordination principle are 
extraordinarily problematic, if not futile. In an argument that complements Kurland's use of indirect evidence to connect Brown to the color-blindness principle, ${ }^{128}$ Seidman contends that there "are significant difficulties" with any view that the Court "was prepared to announce and insist upon a [progressive] moral vision for the country" in 1954. To suggest that the justices were "prepared to say that[,] as a matter of justice, certain [racial] groups were required to exercise at least a modicum of power" is to "[turn] Brown into an anomaly, a decision that is radically discontinuous not only with what came before, but also with what has followed." Specifically, the Court's postBrown rulings are "entirely dominated by the rhetoric of individualism," which informs the color-blindness principle. ${ }^{129}$

While Seidman declines to follow Kurland's example of attempting to provide instances of post-Brown rulings that reflect the color-blindness concept and a discussion of the Court's abandonment of this principle (however temporary), he matches his colleague's effort to point up the significance of the "integrationist ideology" of the NAACP. Any attempt to link Brown to the racial subordination principle, he maintains, "coexists uneasily" with the fact that the lawyers of the NAACP "attacked separate-group identity and insisted on the homogenizing, unifying, and rationalizing force of public education." Indeed, "Thurgood Marshall perfectly captured this individualist strain [of the color-blindness concept]" when he said during oral argument over the matter of the implementation of Brown: "Put the dumb colored children in with the dumb white children, and put the smart colored children with the smart white children - that is no problem." "As integrationists, Marshall and his team of lawyers "denied the relevance of group membership and assumed that individuals could establish their own identities independent of a cultural frame of reference." 130

Seidman's disappointment with Brown extends beyond his belief that the promise of the decision amounted to nothing more than a color-blind vision of society that favors the racial status quo. He thinks that the ruling also had the ironic effect of ending any opportunity for the achievement of material equality in the limited area of public education, the very area in which the decision promised reform. Had the Court taken the "separate-but-equal" doctrine "seriously," he suggests, "it might have used segregationist ideology as a lever to pry loose from white society massive resources that could have 
made the promise of equal treatment a reality." In other words, "[m]aking separate facilities truly equal would have necessitated compensation for all the associational and intangible differences caused by isolation from the dominant culture." By maintaining the inherent inequality of separate facilities, however, the Court prevented black school children from receiving "the kind of money that might have really made a difference."131

Seidman concedes that "this scenario is hopelessly utopian," given that "the cost of pursuing endless individual equalization suits throughout the country far exceeded the resources of either the NAACP or the courts that would have had to hear them." But he concludes that this fact (and, presumably, the Court's adoption of the color-blindness principle) "marks [Brown as] a tactical retreat in the guise of a bold advance." Since the Court could not "make good on the promise of [the "separate-but-equal" principle], [it] utilized a rhetorical flourish to escape the trap it had set for itself"; the justices "effectively freed [themselves] from the obligation of insuring that [racially segregated public schools] were equal." In short, "[f]ar from insisting upon and implementing a substantive vision of the good, the Court resorted to an empty slogan and thus avoided a serious engagement with the evils of racism." 132

Seidman concedes that, "[o]ver the short term," Brown gave blacks "a potent rhetorical weapon in the struggle against both white racism and black nationalism." Brown, he elaborates, "[held] out the possibility of peaceful change" and thus became "the core of the modern civil rights movement." 133 Echoing McDowell, ${ }^{134}$ he also allows that "[t]he elliptical and contradictory wording of the [implementation] decision constituted a self-conscious invitation to continued dialogue and conflict." This ruling inspired the pursuit of "[r]esult-oriented remedies" for segregation (after ostensibly neutral state remedies proved unavailing) and ultimately yielded decisions that approved court-ordered busing and the use of racial quotas as remedial measures. ${ }^{135}$

But Seidman laments: "[T]he creative energy that Brown engendered ["eventually"] ran its course." Indeed, he contends that, "[o]ver the longer term," the decision "has served to deaden political debate and to legitimize the status quo." $\mathrm{He}$ returns to his earlier observations to explain this unfortunate effect. "No understanding of Brown can be complete," he reiterates, "without an appreciation of the fact that the NAACP, for ideological reasons of its own, had embraced the overruling of Plessy and 
the creation of an integrated society as its central goal." He ascribes the Association's pursuit of integration, as opposed to the "ultimate goal" of material equality for AfricanAmericans, to a willingness "to compromise," borne of a desire for a "sense of closure." "[A] sense of closure," however, "is hardly conducive to continued struggle," since plaintiffs who secure precisely what they ask for are "in a weak position to demand still more." Seidman observes: "What was once an eloquent insistence on 'simple justice' soon begins to sound like incessant whining." 136

Brown provided "a false sense of closure and resolution," Seidman maintains, because "the Court has never [even] given us a coherent explanation of what it means for a school district to be unitary," let alone inspired policies that promote greater material equality for African-Americans. Americans came to understand "that the Brown Court offered the country a kind of deal, and, from the perspective of defenders of the status quo, not a bad one at that." "[T]he flip side of [the] aphorism [that separate facilities are inherently unequal]," he explains, "was that once white society was willing to make facilities legally nonseparate, the demand for equality had been satisfied and blacks no longer had just cause for complaint." (Presumably, Seidman also believes that Brown's connection to the color-blindness principle facilitated the Burger Court's and the Rehnquist Court's abandonment of remedial racial classifications.) Although "many blacks remained poor and disempowered" (to say nothing of segregated) after Brown, "their status was now no longer a result of the denial of equality"; rather, "it marked a personal failure to take advantage of one's definitionally equal status." Brown, in short, "created a world where we need no longer be concerned about inequality because the races are now definitionally equal." The decision "seemed to mark the victorious climax of a long and heroic struggle for social justice fought by groups that were outside the political mainstream." In reality, it "[gave] us a kind of amusement-park version of social change," in which we "experience the frisson that comes with upheaval and revolt, all the while secure in the knowledge that we need not suffer any of the discomfort and insecurity that would accompany an actual redistribution of social resources."137

\section{Conclusion}


That certain non-originalists as well as originalists strongly criticize Brown should not obscure the fact that it remains perhaps the most highly regarded decision in the history of the Supreme Court. Indeed, even the spiritedness of Brown's critics is testimony to the standing of the decision. For efforts to reveal to one's jurisprudential colleagues that the emperor has no clothes nevertheless represent a tacit admission of the emperor's status.

While the implicit teaching of Brown's critics is to emphasize the decision's standing, the explicit contribution of these scholars is to reveal the vulnerability of current claims that the color-blindness principle or, alternatively, the racial subordination principle informs the decision. The group orientation of the holding in Brown and of the implementation decision, combined with the fact that the Court never invoked the individualistic color-blindness principle in its post-Brown rulings, complicate the efforts of originalists to prove that the desegregation decision served to declare even "benign" racial classifications unconstitutional. By the same token, the Court's failure in Brown to discuss the complex vision of social reality at the heart of the racial subordination principle, combined with the fact that the petitioners' in the case merely called for the elimination of racial classifications in education, render problematic the efforts of nonoriginalists to demonstrate that the desegregation decision permitted racial classifications whose purpose is to aid the victims of discrimination. In short, as Herbert Wechsler suggested five years after Brown, ${ }^{138}$ the decision appears to afford insufficient guidance regarding the matter of remedial racial classifications.

In view of the inadequacies of scholarly efforts to link Brown to either the colorblindness principle or the racial subordination principle, one must conclude that competing interpretations of social fact (as opposed to a shared concern for the rule of law) inform the current debate over the legacy of the desegregation decision. While "living Constitution" proponents would prefer to ground the racial subordination principle in precedent (especially the Court's most celebrated decision), their jurisprudential position does not preclude - indeed, it encourages - judicial reference to social fact as a means of giving content to constitutional rights. They believe that evidence suggesting the extensiveness of and white responsibility for racial oppression 
warrants judicial resort to the racial subordination principle in equal protection controversies.

Originalists, by contrast, are jurisprudentially committed to basing the colorblindness principle upon a traditional legal foundation. Indeed, even if Brown clearly established the unconstitutionality of all racial classifications, originalists would judge the validity of this ruling by reference to the framers' intentions. In view of this observation, scholarly efforts to reconcile Brown with originalist premises assume added significance. For, if Brown contravened the intentions of the framers of the Fourteenth Amendment, then originalism not only brands one of the most honored Supreme Court opinions an illicit constitutional innovation, but also precludes judicial recourse to the color-blindness principle. As Laurence Tribe observed, ${ }^{139}$ if the framers did not intend to prohibit certain racial classifications that worked to the detriment of blacks, one is hard pressed to conclude that, according to the intentions informing the Fourteenth Amendment, racial classifications designed to overcome prejudice are unconstitutional. In the absence of a convincing originalist defense of Brown, originalists must base their support for the color-blindness principle upon a non-traditional foundation $-\mathrm{a}$ vision of social reality that denies the existence of a strong linkage between racial group membership and social status.

The originalists' belief in the insufficiency of empirical arguments of this sort, and the unlikelihood of the appearance of a compelling originalist defense of Brown, ensure the continuation of scholarly efforts to associate the desegregation decision with the color-blindness principle. These arguments, in turn, should prompt "living Constitution" proponents to continue efforts to establish a link between Brown and the racial subordination principle. If the battle over Brown's legitimacy is any guide to the battle over the decision's legacy, however, the achievement of a consensus over legal argument is contingent upon securing a consensus over social fact. Yet agreement over the relationship between race and social status appears far less likely than the consensus that eventually developed regarding the oppressive nature of segregation. Indeed, the only certainty in the continuing struggle over Brown's legacy is that the meaning of the decision has been and will be partly a function of something over which the Warren 
Court justices had no control - contemporary political forces that attempt to enlist the moral authority of the Supreme Court's most celebrated ruling. 
Notes

1347 U.S. 483 (1954). Brown was one of four consolidated state cases involving racial segregation in public schools at the elementary and secondary school levels. The other three cases came from South Carolina (Briggs v. Elliott), Virginia (Davis v. County School Board of Prince Edward County, Virginia), and Delaware (Gebhart v. Belton). Bolling v. Sharpe, 347 U.S. 497 (1954), a companion case to Brown, involved the public schools of the District of Columbia, which were under the control of the national government.

${ }^{2}$ Jack M. Balkin, ed., What Brown v. Board of Education Should Have Said: The Nation's Top Legal Experts Rewrite America's Landmark Civil Rights Decision (New York: New York University Press, 2001), 4. For an extensive (although by no means exhaustive) listing of scholars who pay tribute to the Brown decision, see Michael J. Perry, The Constitution, the Courts, and Human Rights: An Inquiry Into the Legitimacy of Constitutional Policymaking by the Judiciary (New Haven: Yale University Press, 1982), 167n.8.

${ }^{3}$ See, e.g., James Reston, “A Sociological Decision," New York Times, 18 May 1954, Late City edition; and the "Southern Manifesto," Congressional Record, Senate, vol. 102, Part 4, p.4515, March 12, 1956.

${ }^{4}$ In his opinion for a unanimous Court, Chief Justice Earl Warren maintained that segregation violates the concept of equal protection because the practice "generates a feeling of inferiority [in black children] as to their status in the community that may affect their hearts and minds in a way unlikely ever to be undone." He continued: "Whatever may have been the extent of psychological knowledge at the time of Plessy $v$. Ferguson, this finding is amply supported by modern authority." Warren supported this statement with a footnote that referred to the social science evidence of the petitioners in the case (Brown v. Board of Education of Topeka, Kansas, 347 U.S. 483, 494n.11 [1954]). For perhaps the most famous critique of this rationale from a proponent of the "living Constitution" concept, see Herbert Wechsler, "Toward Neutral Principles of Constitutional Law," Harvard Law Review 73 (1959): 31-35.

5 Jeffrey D. Hockett, “The Battle Over Brown's Legitimacy," Journal of Supreme Court History 28 (2003): 30-53..

${ }^{6}$ In his opinion for the Court, Chief Justice Warren said that the historical sources regarding the meaning of the Fourteenth Amendment were, "at best,...inconclusive" (Brown v. Board of Education of Topeka, Kansas, 347 U.S. 483, 489 [1954]).

${ }^{7}$ For general discussions of the controversial rulings of the Warren Court, which are too numerous to summarize in this endnote, see Lucas A. Powe, Jr., The Warren Court and American Politics (Cambridge: Harvard University Press, Belknap Press, 2000); and Alfred H. Kelly, Winfred A. Harbison, and Herman Belz, The American Constitution: Its Origins and Development, $6^{\text {th }}$ ed. (New York: Norton, 1983), 593-662. 
${ }^{8}$ Green v. County School Board of New Kent County, 391 U.S. 430 (1968).

${ }^{9}$ Milton Handler, "The Supreme Court and the Antitrust Laws: A Critic's Viewpoint,” Georgia Law Review 1 (1967): 350.

${ }^{10}$ Raoul Berger, Government by Judiciary: The Transformation of the Fourteenth Amendment (Cambridge: Harvard University Press, 1977), 411, 4, 412.

${ }^{11}$ Robert H. Bork, The Tempting of America: The Political Seduction of the Law (New York: Simon and Schuster, 1990), 73-74.

${ }^{12}$ Ibid., 116. See Roe v. Wade, 410 U.S. 113 (1973).

${ }^{13}$ Gary L. McDowell, Equity and the Constitution: The Supreme Court, Equitable Relief, and Public Policy (Chicago: University of Chicago Press, 1982), 122. See Swann v. Charlotte-Mecklenburg Board of Education, 402 U.S. 1 (1971).

${ }^{14}$ Bork, The Tempting of America, 101-10 (pp.101, 103 quoted). The relevant decisions are, respectively, Griggs v. Duke Power Co., 401 U.S. 424 (1971); and United Steelworkers of America v. Weber, 443 U.S. 193 (1979).

15438 U.S. 265 (1978).

${ }^{16}$ Bork, The Tempting of America, 246.

${ }^{17}$ Michael W. McConnell, "Originalism and the Desegregation Decisions," Virginia Law Review 81 (1995): 952-53.

${ }^{18}$ Bork, The Tempting of America, 77. See also Richard A. Posner, "Bork and Beethoven," Stanford Law Review 42 (1990): 1373-74; and Earl Maltz, "Brown v. Board of Education and 'Originalism," in Great Cases in Constitutional Law, ed. Robert P. George (Princeton: Princeton University Press, 2000), 142.

${ }^{19}$ See above, n.6.

${ }^{20}$ John G. Wofford, "The Blinding Light: The Uses of History in Constitutional Interpretation," University of Chicago Law Review 31 (1964): 502-33 (pp.502, 513, 503, 531, 530 quoted). See also Walter F. Murphy, "Originalism - The Deceptive Evil: Brown v. Board of Education," in Great Cases in Constitutional Law, ed. Robert P. George (Princeton: Princeton University Press, 2000), 154-74; Laurence H. Tribe, Constitutional Choices (Cambridge: Harvard University Press, 1985), 3-8; James H. Hutson, "The Creation of the Constitution: The Integrity of the Documentary Record," in Interpreting the Constitution: The Debate Over Original Intent, ed. Jack N. Rakove (Boston: Northeastern University Press, 1990), 151-78; Paul Brest, "The Misconceived Quest for the Original Understanding," in Interpreting the Constitution: The Debate Over 
Original Intent, ed. Jack N. Rakove (Boston: Northeastern University Press, 1990), 22762; Mark V. Tushnet, "Following the Rules Laid Down: A Critique of Interpretivism and Neutral Principles," Harvard Law Review 96 (1983): 781-827; and William M. Wiecek, "Clio as Hostage: The United States Supreme Court and the Uses of History," California Western Law Review 24 (1988): 227-68.

${ }^{21}$ See Leon Friedman, ed., Argument: The Oral Argument Before the Supreme Court in Brown v. Board of Education of Topeka, 1952-55 (New York: Chelsea House, 1969), 207-13. See also Berger, Government by Judiciary, 117-33.

${ }^{22}$ Perry, The Constitution, the Courts, and Human Rights, 1-2. Cf. Michael J. Perry, The Constitution in the Courts: Law or Politics? (New York: Oxford University Press, 1994), 136-60, 180.

${ }^{23}$ See Brief for Appellants in Brown v. Board of Education of Topeka, Kansas, Briggs v. Elliott, and Davis v. County School Board of Prince Edward County, Virginia, and for Respondents in Gebhart v. Belton, 1953, 18, 118-20, Papers of the National Association for the Advancement of Colored People, Library of Congress, Manuscript Division, Box II-B-142.

${ }^{24}$ Ronald Dworkin, Law's Empire (Cambridge: Harvard University Press, Belknap Press, 1986), 359-63 (p.362 quoted; emphasis added).

${ }^{25}$ Ronald Dworkin, Taking Rights Seriously (Cambridge: Harvard University Press, 1978), 133-37 (pp.133, 135, 136 quoted). One can find a similar argument in Alexander M. Bickel, "The Original Understanding and the Segregation Decision," Harvard Law Review 69 (1955): 58-65.

${ }^{26}$ Berger, Government by Judiciary, 283-311, 373-96 (p.284 quoted). See also Perry, The Constitution, the Courts, and Human Rights, 70-75.

${ }^{27}$ For a listing and discussion of scholars who contend that Brown is inconsistent with the original understanding of the Fourteenth Amendment, see McConnell, "Originalism and the Desegregation Decisions," 950-52.

${ }^{28}$ McConnell begins his essay by attempting to play down the historical evidence that supports the conventional view that the framers of the Fourteenth Amendment did not regard public school segregation as a violation of the equal protection clause (ibid., 955-84).

${ }^{29}$ Ibid., 953, 1140.

${ }^{30}$ Michael J. Klarman, "Brown, Originalism, and Constitutional Theory: A Response to Professor McConnell," Virginia Law Review 81 (1995): 1881-1936 (p.1884 quoted). 
${ }^{31}$ Maltz, "Brown v. Board of Education and 'Originalism,"' 142-45 (p.145 quoted). See also Earl M. Maltz, "Originalism and the Desegregation Decisions - A Response to Professor McConnell," Constitutional Commentary 13 (1996): 223-31; and Earl M. Maltz, "A Dissenting Opinion to Brown," Southern Illinois University Law Journal 20 (1995): 93-98. Cf. Michael W. McConnell, “The Originalist Justification for Brown: A Reply to Professor Klarman,” Virginia Law Review 81 (1995): 1937-55.

${ }^{32}$ Bork, The Tempting of America, 75-76, 144, 82 (emphasis added). See also Robert H. Bork, "Neutral Principles and Some First Amendment Problems," Indiana Law Journal 47 (1971): 14-15.

${ }^{33}$ Bork has considerable support for the proposition that the framers of the Constitution did not anticipate that judges would seek to discover the subjective intentions behind legal documents (see H. Jefferson Powell, "The Original Understanding of Original Intent," in Interpreting the Constitution: The Debate Over Original Intent, ed. Jack N. Rakove [Boston: Northeastern University Press, 1990], 53-115; and Howard Gillman, "The Collapse of Constitutional Originalism and the Rise of the Notion of the 'Living Constitution' in the Course of American State-Building," Studies in American Political Development 11 [1997]: 206.) But the notion that seemingly abstract constitutional language reveals that the framers of the Constitution or of the Fourteenth Amendment viewed judicial decision-making as a discretionary exercise, or that they intended for judges to regard constitutional provisions as relative to time and circumstance - a notion that Bork simultaneously uses and excoriates - is lacking in evidentiary support (see above, n.26 and accompanying text).

${ }^{34}$ Bork, The Tempting of America, 169.

${ }^{35}$ Ibid., 78-81 (pp.78, 81 quoted; emphasis in original). See also ibid., 145-46, 187-93, 213-14.

${ }^{36}$ Ronald Dworkin, Freedom's Law: The Moral Reading of the American Constitution (Cambridge: Harvard University Press, 1996), 299.

${ }^{37}$ McConnell, "Originalism and the Desegregation Decisions," 951n.11. See also Posner, "Bork and Beethoven," 1374-75; Richard A. Posner, The Problems of Jurisprudence (Cambridge: Harvard University Press, 1990), 305-07; Raoul Berger, "Robert Bork's Contribution to Original Intention," Northwestern University Law Review 84 (1990): 1176-83; and David A. J. Richards, "Originalism Without Foundations," New York University Law Review 65 (1990): 1379-82.

${ }^{38}$ Maltz, "Brown v. Board of Education and 'Originalism," 146-47 (emphasis in original), 150, 146. See also Michael J. Klarman, "The Puzzling Resistance to Political Process Theory," Virginia Law Review 77 (1991): 815-19; Klarman, “Brown, Originalism, and Constitutional Theory," 1931-36; and Lino A. Graglia, "'Interpreting' the Constitution: Posner on Bork," Stanford Law Review 44 (1992): 1037-43. 
${ }^{39}$ Dworkin, Taking Rights Seriously, 140-49 (pp.148, 142, 148 quoted).

${ }^{40}$ Antonin Scalia, "Originalism: The Lesser Evil," Cincinnati Law Review 57 (1989): 864, 861, 864.

${ }^{41} 163$ U.S. 537 (1896).

${ }^{42}$ Ibid., 559.

${ }^{43}$ As quoted in Ralph A. Rossum, "Plessy, Brown, and the Reverse Discrimination Cases," American Behavioral Scientist 28 (1985): 785-86.

${ }^{44}$ See Muir v. Louisville Park Theatrical Association, 347 U.S. 971 (1954); Mayor of Baltimore v. Dawson, 350 U.S. 877 (1955); Holmes v. City of Atlanta, 350 U.S. 879 (1955); and Gayle v. Browder, 352 U.S. 903 (1956).

${ }^{45}$ Wechsler, "Toward Neutral Principles of Constitutional Law," 32, 22, 32. See also Herbert Wechsler, Principles, Politics, and Fundamental Law: Selected Essays (Cambridge: Harvard University Press, 1961), xiv; and Herbert Wechsler, "The Nature of Judicial Reasoning," in Law and Philosophy: A Symposium, ed. Sidney Hook (New York: New York University Press, 1964), 297-98.

${ }^{46}$ Bickel used the "living Constitution" concept to defend the legitimacy of Brown (see above, n.25). See also Alexander Bickel, The Least Dangerous Branch: The Supreme Court at the Bar of Politics, 2d ed. (1962; reprint, New Haven: Yale University Press, 1986), 73-110.

${ }^{47}$ Bickel, The Least Dangerous Branch, 63, 59, 63.

${ }^{48}$ Ibid., 61, 69 (emphasis added). While Bickel always maintained the unconstitutionality of remedial racial measures, he initially called for judicial avoidance of constitutional challenges to such "benign" classifications (ibid., 65-72). In his later work, however, he appeared more supportive of aggressive judicial enforcement of the color-blindness concept (Alexander M. Bickel, The Morality of Consent [New Haven: Yale University Press, 1975], 133).

${ }^{49}$ See above, n.1.

${ }^{50}$ Philip B. Kurland, "'Brown v. Board of Education was the Beginning': The School Desegregation Cases in the United States Supreme Court - 1954-1979," Washington University Law Quarterly (1979): 316-19 (pp.318, 319 quoted).

${ }^{51} 373$ U.S. 683 (1963).

${ }^{52}$ Kurland, "'Brown v. Board of Education was the Beginning,"” 320-36 (pp.320, 335-36, 333 quoted; emphasis added). Aside from Goss, Kurland refers, in particular, to 
McNeese v. Board of Education for Community Unit School District 187, Cahokia, Illinois, 373 U.S. 668 (1963); and Griffin v. County School Board of Prince Edward County, 377 U.S. 218 (1964).

${ }^{53}$ Kurland, "'Brown v. Board of Education was the Beginning," 336.

${ }^{54}$ William Bradford Reynolds, "Individualism vs. Group Rights: The Legacy of Brown,” Yale Law Journal 93 (1984): 998.

${ }^{55}$ Ibid., 1000, 997-98.

${ }^{56}$ Kurland, "'Brown v. Board of Education was the Beginning," 403.

${ }^{57}$ Reynolds, “Individualism vs. Group Rights,” 1001, 1003.

${ }^{58}$ Kurland, "Brown v. Board of Education was the Beginning," 403, 316, 315, $336,403$.

${ }^{59}$ Ibid., 403, 316. See Regents of the University of California v. Bakke, 438 U.S. 265, 402-08 (1978) (Blackmun, J., separate opinion).

${ }^{60}$ William Van Alstyne, "Rites of Passage: Race, the Supreme Court, and the Constitution," University of Chicago Law Review 46 (1979): 809.

${ }^{61}$ See, e.g., Bork, The Tempting of America, 171; Graglia, "“Interpreting' the Constitution," 1030-31; and William H. Rehnquist, "The Notion of a Living Constitution," Texas Law Review 54 (1976): 693-706. See also Gillman, “The Collapse of Constitutional Originalism," 242-43.

${ }^{62}$ Van Alstyne, "Rites of Passage,” 781.

${ }^{63}$ Klarman, "The Puzzling Resistance to Political Process Theory," 822. See also Eric Schnapper, "Affirmative Action and the Legislative History of the Fourteenth Amendment," Virginia Law Review 71 (1985): 753-98; and Dworkin, Freedom's Law, 294-95.

${ }^{64}$ Laurence H. Tribe, "In What Vision of the Constitution Must the Law be ColorBlind?" John Marshall Law Review 20 (1986): 204 (emphasis in original). See also Dworkin, Law's Empire, 395-96.

${ }^{65}$ Bork, The Tempting of America, 110.

${ }^{66}$ Ibid., 109. 
${ }^{67}$ Van Alstyne, "Rites of Passage," 809. See also Nathan Glazer, Affirmative Discrimination: Ethnic Inequality and Public Policy (New York: Basic Books, 1975), 196-221.

${ }^{68}$ Van Alstyne, "Rites of Passage,” 803-04 (emphasis in original).

${ }^{69}$ Ibid., 804.

${ }^{70}$ Ibid., 809, 783-84 (emphasis in original).

${ }^{71}$ See above, nn.44-45 and accompanying text.

${ }^{72}$ Rossum, "Plessy, Brown, and the Reverse Discrimination Cases," 788-91 (pp.790-91 quoted).

${ }^{73}$ See above, nn.49-50 and accompanying text.

${ }^{74}$ Bolling v. Sharpe, 347 U.S. 497, 499 (1954) (emphasis added). See also Andreas Auer, "Public School Desegregation and the Color-Blind Constitution," Southwestern Law Journal 27 (1973): 458.

${ }^{75}$ Rossum, "Plessy, Brown, and the Reverse Discrimination Cases," 794 (emphasis is Rossum's).

${ }^{76}$ McDowell, Equity and the Constitution, 98.

${ }^{77}$ Rossum, "Plessy, Brown, and the Reverse Discrimination Cases,” 797.

${ }^{78}$ See above, n.5 and accompanying text.

${ }^{79}$ McDowell, Equity and the Constitution, 100. See Brown v. Board of Education of Topeka, 349 U.S. 294 (1955).

${ }^{80}$ Rossum, "Plessy, Brown, and the Reverse Discrimination Cases," 794.

${ }^{81}$ McDowell, Equity and the Constitution, 114 (emphasis in original), 11, 110.

${ }^{82}$ Rossum, "Plessy, Brown, and the Reverse Discrimination Cases,” 795, 801.

${ }^{83}$ Ibid., 791-93, 799-800 (quoted).

${ }^{84}$ Ibid., 800-01. See also McDowell, Equity and the Constitution, 130-32, 154 n.37.

${ }^{85}$ The term is taken from Bork, The Tempting of America, 153. 
86418 U.S. 717 (1974).

${ }^{87}$ Pasadena Board of Education v. Spangler, 427 U.S. 424 (1976).

${ }^{88}$ See above, n.14 and accompanying text.

89426 U.S. 229 (1976).

${ }^{90}$ Ibid., 240.

${ }^{91} 490$ U.S. 642 (1989).

${ }^{92}$ Congress overturned Ward's Cove when, in the Civil Rights Act of 1991, it shifted the burden of proof back to employers (Henry J. Abraham and Barbara A. Perry, Freedom and the Court: Civil Rights and Liberties in the United States, $7^{\text {th }}$ ed. [New York: Oxford University Press, 1998], 442-45).

93488 U.S. 469 (1989).

${ }^{94}$ Wygant v. Jackson Board of Education, 476 U.S. 267 (1986).

${ }^{95}$ Korematsu v. United States, 323 U.S. 214 (1944).

${ }^{96}$ Tribe, "Must the Law Be Color-Blind?" 202 (emphasis in original).

${ }^{97}$ See above, nn.41-42 and accompanying text.

${ }^{98}$ Tribe, "Must the Law Be Color-Blind?" 203. See also Leslie G. Carr, "ColorBlind” Racism (London: SAGE, 1997), 114-18.

${ }^{99}$ Tribe, "Must the Law Be Color-Blind?" 204-05.

${ }^{100}$ See above, nn.47-48 and accompanying text.

${ }^{101}$ Dworkin, Law's Empire, 396. See also Tribe, "Must the Law Be ColorBlind?" 205-06.

${ }^{102}$ Dworkin, Law's Empire, 394-95.

${ }^{103}$ Ronald Dworkin, A Matter of Principle (Cambridge: Harvard University Press, 1985), 298-302 (p.302 quoted).

${ }^{104}$ See Dworkin, Taking Rights Seriously, 131-32; Dworkin, Law's Empire, 221, $389-92$.

${ }^{105}$ Dworkin, A Matter of Principle, 294-95. 
${ }^{106}$ See above, nn.44-45 and accompanying text.

107 Alan Freeman, “Antidiscrimination Law: The View From 1989," Tulane Law Review 64 (1990): 1416, 1414, 1416, 1414.

${ }^{108}$ See above, nn.47-48 and accompanying text.

${ }^{109}$ Freeman, “Antidiscrimination Law: The View From 1989,” 1411, 1434, 1411, 1409.

${ }^{110}$ Ibid., 1407, 1429, 1412, 1433, 1412, 1409, 1435.

${ }^{111}$ Morton J. Horwitz, "The Jurisprudence of Brown and the Dilemmas of Liberalism," Harvard Civil Rights-Civil Liberties Law Review 14 (1979): 608.

${ }^{112}$ See Charles A. Lofgren, The Plessy Case: A Legal-Historical Interpretation (New York: Oxford University Press, 1987), 93-115.

${ }^{113}$ Horwitz, "The Jurisprudence of Brown,” 606, 603-04.

114 David A. Strauss, "Discriminatory Intent and the Taming of Brown," University of Chicago Law Review 56 (1989): 946, 942-43.

${ }^{115}$ See above, n.5 and accompanying text.

116 As evidence of Brown's connection to the racial subordination principle, Strauss refers to the Warren Court's decision, Loving v. Virginia, 388 U.S. 1 (1967), which held that Virginia's anti-miscegenation statute violated the equal protection clause of the Fourteenth Amendment (Strauss, "Discriminatory Intent and the Taming of Brown," 941, 948n.43). But the Court's reasoning -- that such laws can be "justif[ied] [only] as measures designed to maintain White Supremacy" (338 U.S. 1, 11 [1967]) - is compatible with the color-blindness principle.

${ }^{117}$ Strauss refers to, among other decisions, Green v. County School Board of New Kent County, 391 U.S. 430 (1968), where the Court held that the New Kent County school board's "freedom-of-choice plan" was an unacceptable method of complying with the Brown decision (Strauss, "Discriminatory Intent and the Taming of Brown," 949n.46). The decision indicated that states could not discharge their constitutional obligation under the Fourteenth Amendment simply by removing legally imposed attendance assignments based upon race. Rather, compliance with Brown henceforth depended upon whether the racial composition of schools reflected that of the school-age population. Kurland contends that this decision "marked a new beginning [after Brown and the early implementation decisions], for it started the changes in the meaning of desegregation from elimination of the use of racial factors in pupil assignment to homogenization of the student population within each school district and beyond" 
(Kurland, "'Brown v. Board of Education Was the Beginning,"” 337). See also above, n.8 and accompanying text.

${ }^{118}$ Strauss, "Discriminatory Intent and the Taming of Brown," 954 (emphasis added).

${ }^{119}$ See above, nn. 71-84 and accompanying text.

${ }^{120}$ See above, nn.100-110 and accompanying text.

${ }^{121}$ Richard Delgado and Jean Stefancic, "The Social Construction of Brown $v$. Board of Education: Law Reform and the Reconstructive Paradox," William and Mary Law Review 36 (1995): 550-51.

${ }^{122}$ Ibid., 554-58, 562 (pp.554, 556, 562 quoted).

${ }^{123}$ Ibid., 557-58, 562, 569, 549, 569.

${ }^{124}$ See above, nn.82-83 and accompanying text.

${ }^{125}$ For Laurence Tribe's attempt to claim Justice Harlan's Plessy dissent for proponents of the racial subordination principle, see above, nn.96-97 and accompanying text.

${ }^{126}$ Delgado and Stefancic, "The Social Construction of Brown," 562, 563-64. See also above, nn.92-93 and accompanying text.

${ }^{127}$ Delgado and Stefancic, “The Social Construction of Brown,” 564, 569, 570.

${ }^{128}$ See above, nn.49-53.

${ }^{129}$ Louis Michael Seidman, "Brown and Miranda," California Law Review 80 (1992): 711-12.

${ }^{130}$ Ibid., 712, 712n.122.

${ }^{131}$ Ibid., 713.

${ }^{132}$ Ibid., 714.

${ }^{133}$ Ibid., 715.

${ }^{134}$ See above, nn.78, 80 and accompanying text.

${ }^{135}$ Seidman, "Brown and Miranda," 716.

${ }^{136}$ Ibid., 715-17. 
${ }^{137}$ Ibid., 747 (emphasis added), 752, 717, 752-53.

${ }^{138}$ See above, nn.44-45 and accompanying text.

${ }^{139}$ See above, n.64 and accompanying text.

Author's Note: I would like to thank the American Philosophical Society and the Earhart Foundation for grant support that facilitated the completion of this paper.

Recebido em: 15 de julho de 2017.

Aceito em: 25 de julho de 2017. 